\title{
Silage review: Recent advances and future technologies for baled silages ${ }^{1}$
}

\author{
W. K. Coblentz ${ }^{* 2}$ and M. S. Akins $†$ \\ *USDA-Agricultural Research Service, US Dairy Forage Research Center, Marshfield, WI 54449 \\ †Department of Dairy Science, University of Wisconsin, Madison 53706
}

\section{ABSTRACT}

Although the concept of ensiling large-round or large-square bales dates back to the late 1970s, many refinements have been made to both equipment and management since that time, resulting in much greater acceptance by small or mid-sized dairy or beef producers. This silage preservation technique is attractive to producers for several reasons, but the primary advantage is a reduced risk of weather damage to valuable forage crops compared with preservation as dry hay. Most core principles for making high-quality precisionchopped silages also apply to baled silages; among these, establishing and subsequently maintaining anaerobiosis are priorities. For baled silages, these priorities are critical, in part because recommended moisture concentrations (45 to $55 \%$ ) are drier, and particle length is much longer. These factors act to restrict the rate and extent of silage fermentation, often resulting in less production of desirable fermentation acids and a greater (less acidic) final $\mathrm{pH}$. Within this context, preservation of baled silages can be improved by applying polyethylene (PE) film wraps promptly, using an appropriate number of PE film layers (6 to 8), selecting a storage site free of sharp objects or other debris, and by monitoring wrapped bales closely for evidence of puncture, particularly by birds or vermin. Under certain conditions, such as those in which the bale moisture of highly buffered forages exceeds the recommended range, the heterogeneous nature of baled silages coupled with a restricted rate and extent of fermentation may increase susceptibility to clostridial activity compared with precision-chopped forages ensiled at comparable moisture concentrations. To date, research evaluating inoculants or other additives designed to improve the fermentation of challenging forages or aerobic stability has been limited, but should not be discontinued. Development of PE film embedded with an oxygen-limiting barrier has yielded positive results in some trials; however,

Received August 18, 2017.

Accepted September 26, 2017.

${ }^{1}$ This article is part of a special issue on silage management.

${ }^{2}$ Corresponding author: wayne.coblentz@ars.usda.gov most differences between these novel formulations and reputable commercial PE film have been related to decreases in yeast and mold counts at the surface layer. Related assessments of fermentation or nutritive value determined on a whole-bale basis have been less conclusive. Baled silages can be produced successfully by adhering to straightforward management principles; as such, this form of silage production is likely to remain popular for the foreseeable future.

Key words: aerobic stability, anaerobiosis, baled silage, fermentation, polyethylene silage wrap

\section{INTRODUCTION}

\section{General Comments}

Brief Historical Perspective. Although the concept of ensiling large-round or large-square bales dates back to the late 1970s (Savoie and Jofriet, 2003), many refinements have been made to the process since that time with respect to both equipment and management, resulting in much greater acceptance by forage producers, especially for use on small and mid-sized dairy or beef operations. Most core principles for making, and then preserving, high-quality precision-chopped silages also apply to baled silages. Most prominent among these are the establishment and subsequent maintenance of anaerobiosis within the silo or silage bale. Originally, this critical management requirement was the Achilles heel of the baled silage preservation method as producers often struggled with preformed silage bags that fit over the bale, and needed to be tied by hand to establish a seal that initiated oxygen depletion. McDonald et al. (1991) summarized some early history of baled silages, noting that an increased incidence of listeriosis was observed in sheep that coincided with the introduction of baled silage in Europe. Continuing that discussion, it also was noted that a slow infusion of oxygen into the silage bale, potentially facilitated by hand-tying a preformed bag, created favorable conditions for Listeria to proliferate. In addition, any holes made in preformed bags by birds or vermin caused the bag to billow in the wind, thereby flushing the silage bale with oxygen. Over time, producers have migrated away from preformed 
silage bags, and now use mechanized wrapping systems that apply multiple layers of stretch polyethylene (PE) film to seal each bale; however, these changes were not without problems, particularly those related to films of poor quality that often compromised the integrity of the anaerobic silo environment, resulting in large DM and nutritional quality losses (Savoie and Jofriet, 2003). Today, most of these issues have been resolved, and baled silage has gained wide acceptance with dairy and beef producers. Currently, bale-wrapping systems generally are of 2 types: (1) individual, in which each bale is wrapped as a completely sealed, stand-alone unit or silo; or (2) in-line, where bales are positioned end to end with PE-film wrap applied around the circumferential surface of large-round bales. Individual wrapping systems offer advantages with respect to flexibility, and potential for marketing because the PE film does not need to be removed to transport the silage bales. In-line systems offer advantages of increased efficiency, less film usage per bale, and essentially limitless capacity because a row of silage bales can be extended to virtually any length. In-line systems generally work better when feeding occurs on the same farm where bales are stored because the PE-film wrap needs to be cut to free bales for feeding, thereby flushing the exposed bale with oxygen and complicating the potential for marketing the forage as a cash crop.

Advantages and Disadvantages. Almost a quarter-century ago, numerous potential advantages of baled silage preservation techniques compared with conventional dry hay or precision-chopped silages were recognized (Vough and Glick, 1993). These advantages largely remain relevant today, and include (1) reduced risks of weather damage compared with a dry hay system; (2) increased management flexibility because the same equipment can be used for both dry hay or baled silage; (3) lower fixed and operating costs because less specialized equipment and no storage structures are required; (4) reduced field losses (especially legume leaves) compared with dry hay; (5) theoretically limitless storage capacity without additional investment, provided the integrity of plastic wraps is maintained; (6) little potential for effluent compared with chopped silages; and (7) increased flexibility with respect to feeding options. Concurrently, several disadvantages are associated with baled silages, also noted by Vough and Glick (1993), that can be condensed to about 3 major themes: (1) fermentation is inherently restricted, resulting in a less stable final silage product, often containing greater concentrations of unfermented sugars; (2) as a result of restricted fermentation, an acceptable final silage product is critically dependent on maintaining the integrity of the PE film and the anaerobic environment within the sealed bale; and (3) silage PE films represent additional cost, and they continue to present a disposal problem for producers after feeding. The objectives of this review are to discuss comprehensively the improvements to our understanding of baled silage management occurring over the last 2 decades, and then hypothesize what specific unresolved problems are worthy of continued present and future research.

\section{Comparisons of Baled Silages with Dry Hay}

One of the most compelling advantages of making baled silages compared with dry hay is that less wilting time is required before baling, thereby reducing risks of damage from inclement weather. However, there have been relatively few direct comparisons of hay and baled silage produced from the same forage source. Two factors related to hay storage further complicate interpretation; hay stored outdoors has potential for weathering (Collins et al., 1995), and moist hay packages are prone to heat spontaneously (Rotz and Muck, 1994). Both of these factors might further erode the nutritive value of hays beyond the simple risk of rain damage during the (pre-baling) wilting period. Hancock and Collins (2006) conducted 2 trials comparing alfalfa (Medicago sativa L.) forage preserved as baled silage with dry hay that was stored outdoors for approximately 5 mo. These trials not only illustrate advantages of baled silages over hays (Figure 1), but also the confounding issues associated with any direct comparison of the 2 preservation types. Dry hays produced from both trials incurred about 5 mo of weathering, and also at least modest spontaneous heating, resulting in internal bale temperatures in both trials that exceeded $45^{\circ} \mathrm{C}$. In addition, multiple rainfall events occurred in trial 2 before the alfalfa forage was wilted adequately to bale as dry hay; in contrast, baled silages were not affected because they were baled and wrapped before the rainfall events occurred. The additional rain damage incurred during production of dry hay during trial 2 resulted in greater concentrations of NDF and ADL on a pre-storage basis for dry hay compared with baled silages. In contrast to dry hays, changes in concentrations of NDF and ADL during storage for baled silages were relatively minor, and likely reflected only modest and largely unavoidable respiratory losses that occurred as oxygen was depleted from the bale following application of the PE-film wrap.

Similar results were observed by Han et al. (2004); in vitro DM disappearance was lower for dry hays compared with baled silages ( mean $=55.3 \%$ moisture) on both a prestorage (53.7 vs. $61.8 \%$ ) and poststorage $(51.3$ vs. $65.5 \%)$ basis. This was largely attributed to leaf shatter caused by the low-moisture concentration of the hay at baling (9.8\%). Furthermore, after offering 
these conserved forages to 340-kg Angus steers, greater voluntary DMI were observed for the baled silages compared with dry hay (2.07 vs. $1.75 \%$ BW). A similar response was observed for total-tract DM digestibility (62.9 vs. $59.2 \%)$, but intakes of digestible DM and $\mathrm{NDF}$, as well as total-tract digestibility of NDF, did not differ statistically between conservation types.

A similar study (Burns and Fisher, 2012) that compared big bluestem (Andropogon gerardi Vitman) hay and baled silages (direct cut or wilted) found no differences between preserved forage types with respect to poststorage concentrations of in vitro true digestibility, CP, and fiber components. However, when these preserved forages were offered to Angus steers (256 \pm $18 \mathrm{~kg}$ ), voluntary DMI tended to be greater for baled
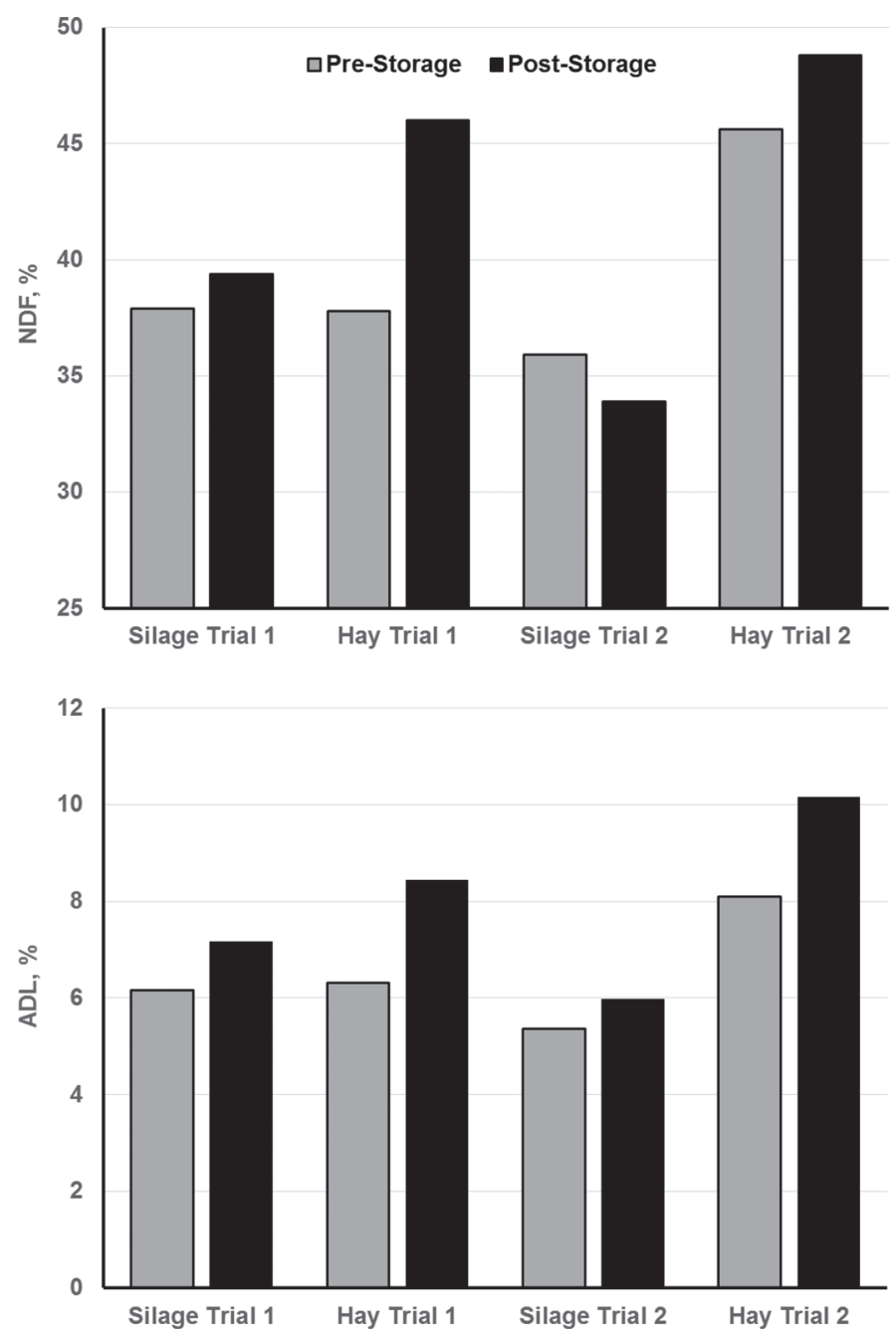

Figure 1. Concentrations of NDF (top) and ADL (bottom) for 2 trials in which alfalfa forage from the same source was preserved as baled silage wrapped in 4 or 6 layers of polyethylene film or dry hay. For trial 2, multiple rainfall events occurred before alfalfa forage could be baled as dry hay. Data are averaged over several treatment factors and adapted from Hancock and Collins (2006). silages (1.72 vs. $1.52 \% \mathrm{BW}$ ), but total-tract digestibilities of DM and fiber components were greater for the dry hays, thereby resulting in no differences between conservation types with respect to digestible intakes of $\mathrm{DM}$ and fiber.

Beck et al. (2009) evaluated wheat forages harvested at either the boot or dough stage of maturity and preserved as either hay or baled silage when offered in a series of trials to Angus beef steers $(\sim 200 \mathrm{~kg})$. Forage maturity and preservation method did not affect ADG when wheat forages comprised either 20 or $40 \%$ of diet. Voluntary intakes of DM by steers were greater for hay compared with baled-silage diets when wheat forage comprised $40 \%$ of the total diet (3.10 vs. $2.77 \%$ of BW), and a similar relationship between conservation treatments was observed for total-tract digestibility of NDF (71.9 vs. $67.3 \%$ of NDF), as well as a tendency for greater total-tract digestibility of DM (73.5 vs. $71.1 \%$ of DM). When wheat forage comprised $40 \%$ of the diet, steers offered baled silage tended to exhibit greater feed efficiency than those offered hay ( 0.27 vs. $0.24 \mathrm{~kg} / \mathrm{kg}$; gain/feed).

Other studies (McCormick et al., 1998; Borreani et al., 2007) compared lactation responses for baled silages and dry hays, but neither attempted simultaneous conservation because weather (wilting) conditions were deemed too erratic for baling dry hay. As a result, production of dry hay was delayed several weeks until weather conditions were more reliable, resulting in dry hays of poorer nutritive value, as well as greater reliance on concentrates to meet the energy requirements of lactating cows. McCormick et al. (1998) compared annual ryegrass (Lolium multiflorum L.) forage harvested as either hay, precision-cut silage, or baled silage and found poorer forage intakes for lactating cows offered baled silage (7.9 $\mathrm{kg}$ of DM) or hay (7.8 $\mathrm{kg}$ of DM) compared with precision-cut silage $(9.2 \mathrm{~kg}$ of $\mathrm{DM})$. These differences were attributed to the longer particle length of baled silage and dry hay, thereby reducing the rate of passage and restricting voluntary intake. No significant differences in milk yield or composition were observed in comparisons of baled silage and hay, but cows offered hay consumed an additional $1.5 \mathrm{~kg} / \mathrm{d}$ of concentrate. For cows receiving hay, the concentrate mix also was fortified with a greater concentration of $\mathrm{CP}$ to compensate for the lower nutritive value of the hay. As a result, feed efficiencies were greater for cows consuming baled silages (1.61 vs. $1.43 \mathrm{~kg}$ of FCM $/ \mathrm{kg}$ of DMI). In a similar comparison, Borreani et al. (2007) offered grass from permanent alpine meadows preserved as dry hay or baled silage to lactating cows in Italy. Because dry hay was harvested later at poorer quality, cows fed baled silage produced greater milk yield, while consuming $1.6 \mathrm{~kg} / \mathrm{d}$ less concentrate than cows fed the 
dry-hay diet. These studies illustrate a primary advantage of baled silages over dry hay in regions where wilting conditions are unreliable, particularly during spring or early summer. Normally, baled silages can be harvested at less mature growth stages that require shorter wilting times, potentially resulting in better nutritive value, and less reliance on concentrate feeds to meet the energy requirements of livestock. A recent economic and risk analysis of bale-wrapping technologies concluded that economic benefits of baled silages are most discernable for high-quality forages produced during seasons or time intervals when weather risks or weather-related harvest delays have the greatest negative effects on forage quality (Lacy et al., 2015).

\section{Comparisons of Baled and Precision- Chopped Silages}

Although suggested moisture concentrations for baled silages vary somewhat by source, they generally fall within close proximity to the 45 to $55 \%$ target suggested by Shinners (2003). This target contrasts sharply with moisture concentrations recommended for precision-chopped silages with high buffering capacity and relatively low concentrations of sugar, such as alfalfa ( $\leq 70 \%$ DM; Muck et al., 2003). Furthermore, precision-chopped silages with $<50 \%$ moisture are usually discouraged because of increased risks of respiration (plant-cell or microbial), spontaneous heating, high DM losses, and reductions in nutritive value (Muck, 1988). Because baled silages are usually considerably drier than precision-chopped silages, fermentation is inherently restricted (McDonald and Edwards, 1976). In part, these contrasting moisture recommendations between silage types are related to mechanical issues, where balers generally handle low-moisture forages better than high-moisture forages, and the additional bale weight associated with high-moisture bales poses legitimate safety concerns during handling and transport (Shinners, 2003). In addition, the long-stemmed nature of most baled silages requires diffusion of plant sugars from inside the plant to reach lactic-acid-producing bacteria that are adhered to the outside surface of forage plants, further reducing the rate and extent of fermentation (Nicholson et al., 1991; Muck et al., 2003; Savoie and Jofriet, 2003). Relatively few comparisons are available of baled and precision-chopped silages, and fewer still compare these silage systems at common moisture concentrations. Early research by Nicholson et al. (1991) provides clear contrasting responses between baled and chopped alfalfa-grass forages ( $70 \%$ alfalfa) ensiled at $61 \%$ moisture (Figure 2). The $\mathrm{pH}$ decline for chopped silages was both more rapid and more extensive compared with the baled silages, and this
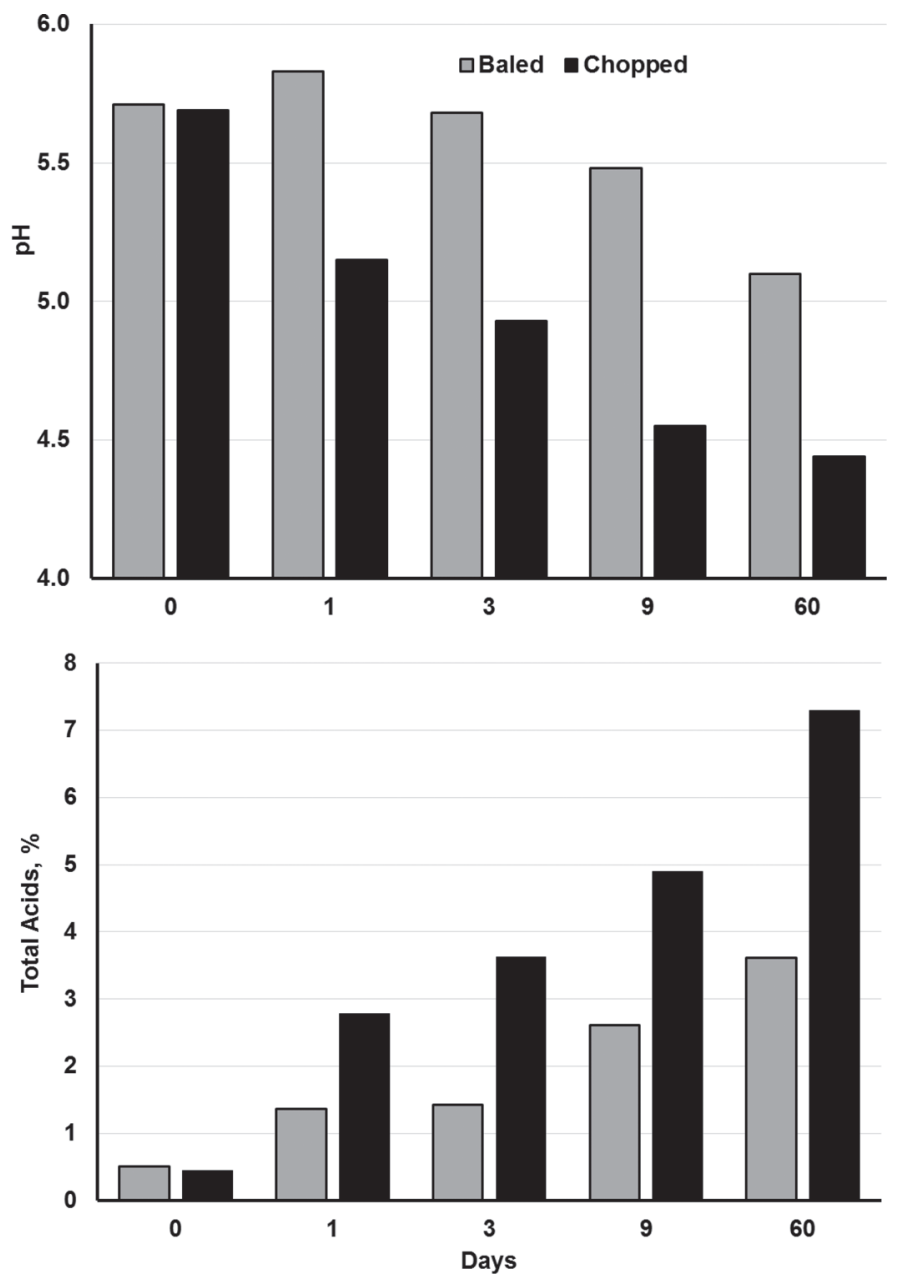

Figure 2. Comparison of fermentation rate and extent for baled and precision-chopped alfalfa-grass forages (70\% alfalfa) ensiled at $61 \%$ moisture as illustrated by $\mathrm{pH}$ change over time (top) and production of total fermentation acids (bottom). Data are adapted from Nicholson et al. (1991).

was facilitated through greater production of fermentation acids. After $60 \mathrm{~d}$ of fermentation, concentrations of lactic acid were almost 3-fold greater for chopped compared with baled silages (5.0 vs. $1.9 \%$ ), whereas residual water-soluble carbohydrates (WSC) were $50 \%$ greater for baled silages (6.6 vs. $4.4 \%$ ), indicating less extensive use of substrate for fermentation in the baled silage.

McCormick et al. (1998) ensiled annual ryegrass in both baled and chopped forms at about $65 \%$ moisture; the final $\mathrm{pH}$ for chopped silage tended to be the most acidic ( $\mathrm{pH}=4.5$ vs. 4.8$)$, but final concentrations of individual fermentation acids did not differ statistically. In addition, typical measures of nutritive value, including $\mathrm{CP}, \mathrm{NDF}, \mathrm{ADF}$, and in vitro true digestibility of DM, did not differ statistically across silage types. Although this contrast between baled and chopped silages 
was less distinctive than that described by Nicholson et al. (1991), the buffering capacity and concentrations of WSC in annual ryegrass forages usually are much more favorable for fermentation than those observed for alfalfa.

Although interpretation was confounded by differences in moisture concentrations between silage types, a survey study conducted in Ireland (McEniry et al., 2006) found that baled silages (mean $=64 \%$ moisture) produced less lactic, acetic, propionic acids, but more butyric acid than chopped silages (mean = $78 \%$ moisture); in addition, greater concentrations of residual WSC were observed within the baled silages following fermentation. As observed previously, NDF, $\mathrm{ADF}$, and in vitro DM digestibility did not differ across silage types. Both Petit et al. (1993) and McCormick et al. (1998) observed reduced forage intakes from baled compared with precision-chopped silages, which might be related to the long-stemmed nature of baled silages (McCormick et al., 1998). However, the effects on subsequent milk production and feed efficiencies within these studies have been inconsistent. Overall, comparisons of feeding baled and precision-cut silages of similar nutritive value suggest the potential for forage intake is reduced for baled silages, particularly when offered in a component feeding system in which forages are fed separately from concentrates. From a silage fermentation perspective, research results suggest that the slower and less extensive fermentation patterns observed for baled silages are more closely linked to restricted availability of sugars to lactic-acid-producing bacteria, rather than interfering effects of oxygen within the bale that are facilitated by increased porosities and lower silage densities created by the drier, long-stemmed nature of baled silages (Muck et al., 2003).

\section{Management Considerations for Baled Silages}

Moisture. Moisture is known widely to encourage more aggressive silage fermentation through greater production of fermentation acids (McDonald and Edwards, 1976; McDonald et al., 1991); however, wet silages, such as chopped alfalfa $>70 \%$ moisture (Muck et al., 2003), or direct-cut grasses in northern Europe, are also subject to problematic secondary clostridial fermentations. Because of the slower fermentation rate and less acidic final $\mathrm{pH}$ (Figure 2), some baled silages might be more problematic in this regard. As such, management of bale moisture is critical during production of successfully preserved baled silages, and many experiments have included bale moisture within the treatment structure because of its profound effects on fermentation. Regardless of forage species, the withinexperiment effects of bale moisture are quite consistent
(Table 1). As bale moisture declines via field-wilting, subsequent production of desirable fermentation acids is reduced, thereby resulting in a less acidic final $\mathrm{pH}$. Similar responses have been associated with advancing plant maturity, which often coincides with drier baled silages (Han et al., 2014). When lactic-acid-dominated baled silages are very wet, such as the grasses ensiled at $\geq 73.7 \%$ and reported by Keles et al. (2009), concentrations of butyric acid $(\geq 0.96 \%)$ exceed target goals of $<0.1 \%$ (Mahanna and Chase, 2003) for stable silages. Similar concentrations of butyric acid (0.99\%) have been observed in baled alfalfa silages made at $59.6 \%$ moisture (Coblentz et al., 2016a); this observation was accompanied by elevated concentrations of $\mathrm{NH}_{3}-\mathrm{N}(19.0 \%$ of total $\mathrm{N})$ that exceed typical targets for legume silages (10 to $15 \%$ of N; Kung and Shaver, 2001), further indicating that some clostridial activity occurred. Based on these results, additional wilting to $55 \%$ moisture before baling or use of a homofermentative inoculant (or both) have been recommended for baled alfalfa silages approaching a $60 \%$ moisture threshold (Coblentz et al., 2016a).

While these concerns with high-moisture baled silages are legitimate, production of high-moisture baled silages throughout the United States is much less common than the contrasting situation of baled silages produced at moisture concentrations falling below the range suggested by Shinners (2003; 45 to $55 \%$ ). There are likely several reasons for this observation, and they might include (1) the inability to consistently measure or estimate forage moisture accurately; (2) lingering concerns about weight and associated safety issues related to producing and handling wet (heavy) silage bales; (3) baler design that is primarily, or co-equally, oriented toward dry hay, and therefore handles dry forages much better than wet forages; (4) producer inexperience with producing baled silage, leading to the habitual mowing of more forage than can be baled and wrapped before it becomes excessively dry; (5) additional security against clostridial fermentations; and (6) relatively limited consequences of excessive wilting, provided the integrity of the PE wrap is maintained. As described previously, the production of desirable fermentation products is restricted within low-moisture baled silages, which leads to limited pH depression. Huhnke et al. (1997) examined legume-grass baled silages produced at 4 locations in Oklahoma, and reported that total fermentation products increased with bale moisture, but concentrations were generally limited to $<2 \%$ of $\mathrm{DM}$, and $<1 \%$ of DM at 2 specific locations, when bale moisture was $\leq 40 \%$. For alfalfa baled silages, Coblentz et al. (2014) found that lactic acid was essentially undetectable $(0.02$ $\pm 0.057 \% ; \mathrm{n}=22$ bales) for forage obtained from the second cutting when bale moisture was $<45 \%$ (Figure 
3), but increased at bale moistures ranging from 45 to $60 \%$. Other studies with alfalfa have been corroborative; Shinners et al. (2009) reported concentrations of lactic acid ranging from 0.10 to $0.58 \%$ of $\mathrm{DM}$ in 2 trials with initial bale moistures ranging from 33.7 to $38.1 \%$. Similarly, Coblentz et al. (2016c) reported a mean lactic acid concentration of $0.11 \%$ of DM across 36 round bales of alfalfa-mixed grass silage ( $82 \%$ alfalfa) made at $40.2 \%$ moisture. Similar responses to low bale moisture have been observed for baled silages comprised of other forage types (Huhnke et al., 1997; Burns and Fisher, 2012).

Given the low-moisture concentration of these baled silages, the likelihood of achieving a final $\mathrm{pH}$ of 4.2, described by McDonald et al. (1991) as sufficient to provide stability against secondary clostridial fermentations is remote. However, low forage moisture has an inhibitory effect on clostridial activity (Leibensperger and Pitt, 1987), and achievement of a low final $\mathrm{pH}$ is relatively unimportant in preserving dry $(<45 \%$ moisture) silages (Muck, 1988). Models of clostridial dominance, such as the one described by Leibensperger and Pitt (1987), suggest that the actual $\mathrm{pH}$ at which the growth of Clostridium tyrobutyricum ceases is fluid, and dependent on a variety of factors that include moisture concentration, forage species, WSC, and buff- ering capacity; however, those modeling efforts largely predate baled silages and the unique nature of their fermentations (see Figure 2). The major risk associated with low-moisture baled silages is aerobic deterioration initiated by loss of integrity by the PE-film bale wrap. Silage fermentations restricted by field-wilting have long been associated with greater residual concentrations of WSC (McDonald and Edwards, 1976), and this has been observed specifically for baled alfalfa silages (Coblentz et al., 2014, 2016c). After ensiling 36 large-round bales of alfalfa-grass at $40.2 \%$ moisture, a mean loss of only 0.4 percentage units of WSC was observed after fermentation was complete (Coblentz et al., 2016c). Silages particularly prone to aerobic deterioration include those generally rich in carbohydrates, as well as those with fermentations restricted by additives or extensive field-wilting (McDonald et al., 1991). Muck et al. (2003) concluded that although a low-moisture concentration inhibits growth rates of yeasts and molds responsible for initiating aerobic deterioration, it also increases porosity of the silage to oxygen and lowers the specific heat of the silage. Thus, poorly sealed baled silages are subject to deterioration through larger pools of residual WSC, as well as increased porosity of the bale to oxygen. Despite these risks, Huhnke et al. (1997) reported that DM losses

Table 1. Effects of within-experiment bale moisture (arranged in descending order) on final silage $\mathrm{pH}$ and concentrations of various fermentation products $^{1}$

\begin{tabular}{|c|c|c|c|c|c|c|c|c|c|}
\hline Reference & Bale type & $\begin{array}{c}\text { Bale } \\
\text { moisture, } \\
\%\end{array}$ & $\mathrm{pH}$ & $\begin{array}{c}\text { Lactic } \\
\text { acid, \% } \\
\text { of DM }\end{array}$ & $\begin{array}{l}\text { Acetic } \\
\text { acid, } \% \\
\text { of DM }\end{array}$ & $\begin{array}{c}\text { Propionic } \\
\text { acid, } \% \\
\text { of DM }\end{array}$ & $\begin{array}{l}\text { Butyric } \\
\text { acid, \% } \\
\text { of DM }\end{array}$ & $\begin{array}{l}\text { Ethanol, } \\
\% \text { of DM }\end{array}$ & $\begin{array}{l}\mathrm{NH}_{3}-\mathrm{N}, \\
\% \text { of } \mathrm{N}\end{array}$ \\
\hline \multicolumn{10}{|l|}{ Alfalfa trials } \\
\hline \multirow[t]{4}{*}{ Shinners et al. (2009) } & Round & 55.5 & 4.79 & 3.79 & 0.83 & - & - & 0.37 & - \\
\hline & Rectangular & 48.8 & 4.86 & 3.83 & 0.81 & - & - & 0.58 & - \\
\hline & Round & 38.7 & 5.46 & 0.47 & 0.33 & - & - & 0.13 & - \\
\hline & Rectangular & 37.4 & 5.46 & 0.40 & 0.37 & - & - & 0.24 & - \\
\hline \multirow[t]{4}{*}{ Shinners et al. (2009) } & Round & 50.4 & 5.34 & 1.40 & 0.45 & - & - & 0.29 & - \\
\hline & Rectangular & 46.0 & 5.47 & 0.72 & 0.33 & - & - & 0.27 & - \\
\hline & Round & 34.0 & 5.63 & 0.08 & 0.24 & - & - & 0.19 & - \\
\hline & Rectangular & 35.5 & 5.60 & 0.18 & 0.25 & - & - & 0.25 & - \\
\hline \multirow[t]{2}{*}{ Borreani and Tabacco (2006) } & Round & 62.7 & 5.10 & 4.82 & 1.83 & 0.01 & 0.04 & - & - \\
\hline & Round & 50.6 & 5.65 & 1.01 & 0.63 & 0.02 & 0.02 & - & - \\
\hline \multirow[t]{2}{*}{ Hancock and Collins $(2006)^{2}$} & Round & 50.2 & 4.91 & 1.82 & 0.52 & 0.06 & 0.06 & - & - \\
\hline & Round & 37.4 & 4.79 & 1.51 & 0.58 & 0.08 & 0.07 & - & - \\
\hline \multirow[t]{2}{*}{ Nicholson et al. (1991) } & Round & 62.3 & 4.84 & 3.80 & 1.78 & - & - & - & - \\
\hline & Round & 51.5 & 5.29 & 2.84 & 1.16 & - & - & - & - \\
\hline \multicolumn{10}{|l|}{ Grass trials } \\
\hline \multirow[t]{3}{*}{ Müller et al. (2007) } & Rectangular & 69.4 & 4.65 & 3.83 & 1.13 & 0.14 & 0.08 & 2.69 & 11.2 \\
\hline & Rectangular & 43.5 & 5.55 & 0.20 & 0.20 & $<0.01$ & $<0.01$ & 1.38 & 3.2 \\
\hline & Rectangular & 32.8 & 5.72 & 0.04 & 0.07 & $<0.01$ & $<0.01$ & 0.86 & 1.6 \\
\hline \multirow[t]{3}{*}{ Keles et al. $(2009)^{2}$} & Round & 77.1 & 4.35 & 7.50 & 3.16 & 0.21 & 0.98 & - & 12.8 \\
\hline & Round & 73.7 & 4.45 & 6.83 & 2.29 & 0.10 & 0.96 & - & 14.0 \\
\hline & Round & 60.8 & 4.58 & 4.55 & 0.38 & 0.01 & 0.12 & - & 9.8 \\
\hline \multirow[t]{2}{*}{ Burns and Fisher (2012) } & Round & 62.7 & 5.2 & 0.50 & 0.87 & 0.03 & 0.03 & 1.16 & - \\
\hline & Round & 46.4 & 5.6 & 0.11 & 0.35 & 0.05 & 0.01 & 0.28 & - \\
\hline
\end{tabular}

${ }^{1}$ For many references, values represent means averaged over other treatment factors.

${ }^{2}$ Bales wrapped with 2 layers of polyethylene film generally were preserved poorly and were excluded from the means. 


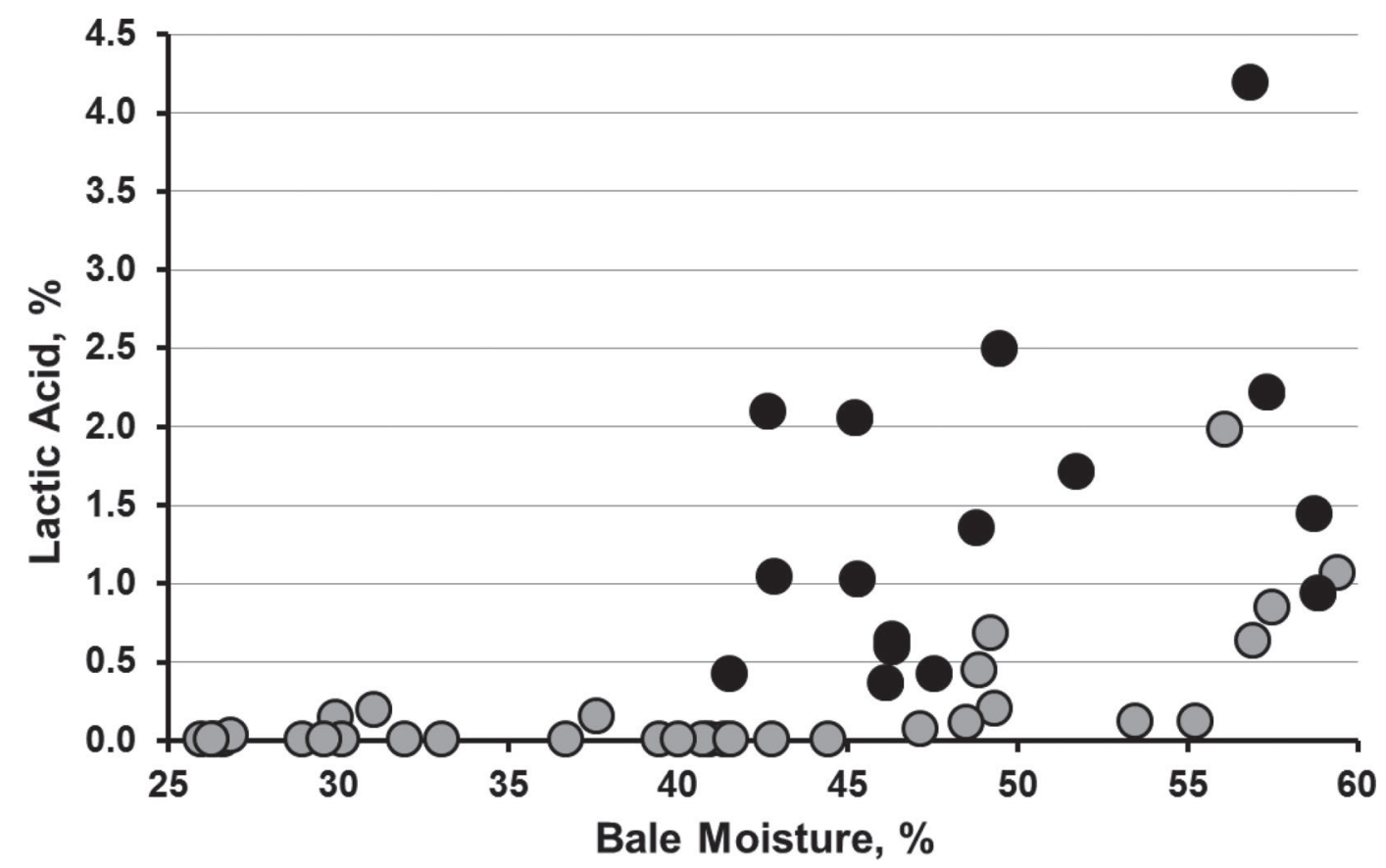

Figure 3. Concentrations of lactic acid in baled alfalfa silages made between 25 and $60 \%$ moisture and obtained from the second (gray circles) and third (black circles) cuttings of the same alfalfa field in 2012 at Marshfield, Wisconsin. For the second cutting (gray circles), lactic acid was essentially undetectable $(0.02 \pm 0.057 \% ; \mathrm{n}=22$ bales $)$ when initial bale moisture was $<45 \%$, but concentrations were greater $(0.57 \pm 0.578 \%)$ in wetter silages. Data are adapted from Coblentz et al. (2014).

from legume-grass baled silages were not related to initial bale moisture. Other studies with relatively dry baled alfalfa silages have reported acceptable (>96\%) recoveries of DM (Shinners et al., 2009; Coblentz et al., 2014, 2016c). One of these studies (Coblentz et al., 2016c) reported a mean loss of 1.2 percentage units of TDN after an extended storage period (127 d), which is minor in scope, and suggests unavoidable respiratory losses during initial depletion of trapped oxygen, rather than prolonged aerobic deterioration from questionable integrity of the PE-film wrap. Despite the limited production of fermentation acids, low-moisture baled silages can be well-preserved provided producers use a well-maintained storage area (Jennings, 2011), and monitor wrapped bales closely for any damage during handling, or from birds or vermin during storage.

$\boldsymbol{A} \boldsymbol{M}$ vs. PM Mowing. Because the rate and extent of fermentation for field-wilted, baled silages are inherently restricted, enhancement of fermentation through creative management strategies is encouraged. Huntington and Burns (2007) and Sauvé et al. (2010) have evaluated the concept of harvesting perennial warmseason (C4) grasses during late afternoon versus early morning, partially attempting to improve WSC concentrations within pre-baled silages, which potentially may improve the substrate pool for silage fermentation, as well as provide some synchronization of energy with the release of ruminally degraded protein in steers consuming these silages. Although a PM harvest increased concentrations of nonstructural carbohydrates in both studies relative to AM-harvested switchgrass (Panicum virgatum L.), eastern gamagrass [Tripsacum dactyloides (L.) L.], or both, the composition of fermentation products within direct-cut baled silages was not consistently improved. Excessive production of ethanol, ranging up to $2.88 \%$ of DM, confounded attempts to detect consistent effects on silage fermentation, although voluntary intakes and improved use of dietary $\mathrm{N}$ were reported for PM-harvested baled silages offered to beef steers (Huntington and Burns, 2007). In another study, alfalfa forages harvested during early evening compared with the following morning, and then ensiled in large rectangular bales at a mean moisture concentration of $47.0 \%$, resulted in improved fermentation characteristics, as well as reduced concentrations of most fiber components for the evening-harvested baled silage (Brito et al., 2008). Furthermore, when offered to late-lactation dairy cows without supplemental concentrate, DMI and production of milk, $4 \%$ FCM, milk fat, and milk protein, as well as $\mathrm{N}$ utilization, were greater for the evening-harvested silage.

Bale Density. For precision-chopped silages, Holmes and Muck (2008) have suggested management targets of $243 \mathrm{~kg}$ of $\mathrm{DM} / \mathrm{m}^{3}$ (15 lb of DM/ $/ \mathrm{ft}^{3}$ ), further refined 
Table 2. Effects of within-experiment bale density on final silage $\mathrm{pH}$ and concentrations of various fermentation products ${ }^{1}$

\begin{tabular}{|c|c|c|c|c|c|c|c|c|c|}
\hline Reference & Forage & $\begin{array}{c}\text { Moisture, } \\
\%\end{array}$ & $\begin{array}{c}\text { DM density, } \\
\mathrm{kg} \text { of } \\
\mathrm{DM} / \mathrm{m}^{3}\end{array}$ & $\mathrm{pH}$ & $\begin{array}{c}\text { Lactic } \\
\text { acid, \% } \\
\text { of DM }\end{array}$ & $\begin{array}{c}\text { Acetic } \\
\text { acid, \% } \\
\text { of DM }\end{array}$ & $\begin{array}{l}\text { Propionic } \\
\text { acid, \% } \\
\text { of DM }\end{array}$ & $\begin{array}{c}\text { Butyric } \\
\text { acid, \% } \\
\text { of DM }\end{array}$ & $\begin{array}{l}\mathrm{NH}_{3}-\mathrm{N}, \\
\% \text { of } \mathrm{N}\end{array}$ \\
\hline \multirow[t]{3}{*}{ Han et al. (2004) } & \multirow[t]{3}{*}{ Alfalfa } & $\begin{array}{l}58.7 \\
58.7\end{array}$ & $\begin{array}{l}207 \\
175\end{array}$ & $\begin{array}{l}4.7 \\
4.9\end{array}$ & $\begin{array}{l}7.00 \\
6.46\end{array}$ & $\begin{array}{l}2.39 \\
3.80\end{array}$ & $\begin{array}{l}0.17 \\
0.08\end{array}$ & $\begin{array}{l}\mathrm{ND}^{2} \\
0.04\end{array}$ & - \\
\hline & & 52.4 & 199 & 4.8 & 7.14 & 3.26 & 0.04 & 0.02 & - \\
\hline & & 52.4 & 167 & 5.1 & 6.28 & 1.99 & 0.07 & 0.05 & - \\
\hline Han et al. (2006) & Pearl millet & 78.3 & 87 & 5.31 & 3.19 & 1.39 & 0.08 & 0.11 & - \\
\hline \multirow[t]{2}{*}{ Han et al. (2006) } & \multirow[t]{2}{*}{ Pearl millet } & 55.8 & 191 & 4.13 & 6.00 & 0.71 & 0.05 & $<0.01$ & - \\
\hline & & 59.4 & 144 & 4.16 & 6.83 & 0.82 & 0.04 & ND & - \\
\hline \multirow[t]{3}{*}{ Keles et al. $(2009)^{3}$} & \multirow[t]{3}{*}{ Grass } & 76.8 & 149 & 4.35 & 7.65 & 3.14 & 0.20 & 0.91 & 12.4 \\
\hline & & 77.4 & 118 & 4.35 & 7.35 & 3.18 & 0.22 & 1.06 & 13.3 \\
\hline & & 61.4 & 137 & 4.65 & 4.70 & 0.39 & ND & 0.13 & 9.8 \\
\hline
\end{tabular}

\footnotetext{
${ }^{1}$ For some references, values represent means averaged over other treatment factors.

${ }^{2} \mathrm{ND}=$ not detected.

${ }^{3}$ Bales wrapped with 2 layers of polyethylene film generally were preserved poorly and were excluded from the means.
}

to $712 \mathrm{~kg}$ (wet weight) $/ \mathrm{m}^{3}\left(44 \mathrm{lb} / \mathrm{ft}^{3}\right)$ to account for varying porosity. In contrast, a recommended target for baled silages of $162 \mathrm{~kg}$ of $\mathrm{DM} / \mathrm{m}^{3}\left(10 \mathrm{lb}\right.$ of $\left.\mathrm{DM} / \mathrm{ft}^{3}\right)$ has been suggested (Jennings, 2011), but this can be exceeded by experienced round-bale operators who are attentive to baler adjustments (bale chamber pressure), swath density, and baler ground speed. For instance, Rhein et al. (2005) reported mean DM densities of 177 and $218 \mathrm{~kg}$ of $\mathrm{DM} / \mathrm{m}^{3}$ (10.9 and $13.5 \mathrm{lb}$ of $\mathrm{DM} /$ $\mathrm{ft}^{3}$ ) for wheat (Triticum aestivum L.) and orchardgrass (Dactylis glomerata L.) baled silages, respectively. More recent research (Tabacco et al., 2013) has reported silage densities for large-round bales that are comparable with some chopped silages (225 to $247 \mathrm{~kg}$ of $\mathrm{DM} / \mathrm{m}^{3}$ ). Several studies have investigated density effects on fermentation characteristics of baled silages (Table 2). Generally, these studies have shown a modest improvement in production of lactic acid with increased bale density, as well as attainment of a more acidic final $\mathrm{pH}$ in studies with alfalfa (Han et al., 2004) and pearl millet [Pennisetum americanum (L.) Leake] (Han et al., 2006). For pearl millet, improvement in final $\mathrm{pH}(4.75$ vs. 5.31) associated with greater initial bale density was particularly noteworthy when initial densities were both relatively low (139 and $87 \mathrm{~kg}$ of $\mathrm{DM} / \mathrm{m}^{3}$, respectively; Han et al., 2006). In another study conducted in Ireland (Keles et al., 2009), improvements in silage fermentation in response to increased density were less clear when baled grasses were relatively wet $(\geq 60.2 \%)$, leading the authors to conclude that the effects of bale density were minimal, once sufficient wrapping layers (4 or 6) were used to establish anaerobiosis.

Bale Chopping Systems. It is accepted widely that the long-particle lengths common to most baled silages limit the rate and extent of silage fermentation (Muck et al., 2003). Irish scientists evaluated this premise in a model system by ensiling grass in laboratory silos under factorial sets of treatments, one of which was a comparison of chopped versus unchopped forage (McEniry et al., 2007a,b). In one experiment, the action of chopping in the absence of any additives improved fermentation by increasing lactic acid, as well as its proportion of all fermentation products; concentrations of butyric acid, ethanol, and $\mathrm{NH}_{3}-\mathrm{N}$ also were reduced (McEniry et al., 2007a). In a second study, chopping reduced final $\mathrm{pH}$, and depressed concentrations of ethanol, butyric acid, and $\mathrm{NH}_{3}-\mathrm{N}$ modestly, but had little effect on most other silage-related response variables. In that study, a trend toward a greater proportion of lactic acid relative to other fermentation products in chopped forages may have been partially responsible for the $\mathrm{pH}$ response (McEniry et al., 2007b). Currently, some balers are designed with pre-cutting systems that can reduce particle length during the baling process, thereby improving bale density by about 15\% (Shinners, 2003). Potential benefits of this concept include (1) improved ease of mixing when baled silages are included in diets blended within TMR mixers; (2) easier removal of si- 
lage by livestock from bales offered in ring-type feeders; and (3) increased bale density that could facilitate the release of sugars from forage plants, thereby improving fermentation (Shinners, 2003). Borreani and Tabacco (2006) examined these concepts in 3 trials with baled alfalfa silages conducted in Italy, concluding that precutting alfalfa within the baler improved DM density by about $4 \%$, but silage fermentation was not substantially improved relative to long-stem (unchopped) baled silages. Additional research is needed to fully assess the potential of pre-cutting systems to improve the fermentation characteristics of baled silages.

Wrapping Delays. Silage producers often inquire about how silage fermentation and quality are compromised when prompt application of PE film after baling is delayed. Current extension recommendations and research results addressing this question include the following recommendations for acceptable time delays before wrapping: (1) within $2 \mathrm{~h}$ of baling (Jennings, 2011); (2) the same day as forage is baled (Hersom and Kunkle, 2014); (3) $\leq 10$ h (Moshtaghi Nia and Wittenburg, 2000); (4) $\leq 24 \mathrm{~h}$ (Coblentz et al., 2016a); or within $48 \mathrm{~h}$ (Garces-Yépez et al., 2001). It is widely known that respiratory processes occurring within moist hays cause marked increases in internal bale temperatures, which become more severe as bale diameter increases (Coblentz and Hoffman, 2009). The subsequent effects of spontaneous heating in hays or silages are widely known to impair protein bioavailability (Goering et al., 1973; Van Soest, 1982; Rotz and Muck, 1994), and to reduce energy density (Coblentz and Hoffman, 2010) due (in part) to oxidation of nonstructural carbohydrates (Rotz and Muck, 1994). A limited number of studies have evaluated fermentation characteristics following time delays between baling and wrapping. Two of these (Moshtaghi Nia and Wittenburg, 2000; Coblentz et al., 2016a) indicate that wrapping delays can lead to reduced production of lactic and total fermentation acids, as well as an elevated final $\mathrm{pH}$ (Table 3). Muck et al. (2003) has suggested that silages compromised initially by access to oxygen might be susceptible to clostridial activity because of the effects on subsequent silage acidity, provided anaerobic conditions have been established. However, there was no solid evidence of this in the 2 studies described in Table 3, although greater concentrations of $\mathrm{NH}_{3}-\mathrm{N}$ were observed following a 3-d delay in wrapping alfalfa bales compared with a 2-d delay (16.2 vs. $12.4 \%$ of N; Coblentz et al., 2016a), and following a 19-h delay in wrapping forage barley (Hordeum vulgare L.) compared with a 10-h delay (8.6 vs. $5.0 \%$ of N; Moshtaghi Nia and Wittenburg, 2000). Strong linear relationships between concentrations of WSC $\left[\mathrm{Y}(\%\right.$ of $\left.\mathrm{DM})=-0.039 \mathrm{x}+6.5 ; \mathrm{R}^{2}=0.634\right]$ or buffering capacity $[\mathrm{Y}(\mathrm{mEq} / \mathrm{kg}$ of $\mathrm{DM})=2.98 \mathrm{x}+316$;
$\left.\mathrm{R}^{2}=0.759\right]$ and bale temperature at wrapping contribute further to the difficulties associated with ensiling forages compromised by wrapping delays (Coblentz et al., 2016a).

Delays in wrapping also have been associated with depressed nutritive value, which is generally consistent with responses observed following spontaneous heating in hays (Rotz and Muck, 1994). Moshtaghi Nia and Wittenburg (2000) reported increased concentrations of ADF, ADIN, and NDIN with time delays as long as 19 $\mathrm{h}$ before wrapping barley forage. Similarly, Coblentz et al. (2016a) reported linear and/or quadratic increases for NDF, ADF, hemicellulose, ADL, NDIN, and ADIN, whereas concentrations of TDN were reduced with similar polynomial effects, as wrapping was delayed from 0 to 3 d (Figure 4). In contrast to these studies, Garces-Yépez et al. (2001) reported elevated internal bale temperatures, but no differences in DM recovery, $\mathrm{pH}$, in vitro OM disappearance, or ADIN within baled bermudagrass [Cynodon dactylon (L.) Pers.] silages wrapped in PE film after delays up to $48 \mathrm{~h}$ in a trial conducted over 2 yr. Inconsistent responses across a limited number of studies make a straightforward recommendation challenging. Obviously, bales should be wrapped as quickly as possible, and ideally within the same day as the forage is baled. Taken in total, the negative effects of an approximate 24-h delay observed across most of these studies appear generally to be minor; perhaps producers should use that timeframe as a guide or threshold, while acknowledging that effects on fermentation and nutritive value might become more serious with longer delays.

Layers of Polyethylene Film. Numerous studies (Keller et al., 1998; Hancock and Collins, 2006; Borreani and Tabacco, 2008; Keles et al., 2009; Coblentz et al., 2016c) have evaluated the number of 1-mil-thick (0.025-mm) layers of PE film used to wrap silage bales as at least a portion of the overall experimental structure. Unlike some other management variables, results from these studies are relatively consistent, and form the basis for solid consensus. Three studies (Hancock and Collins, 2006; Borreani and Tabacco, 2008; Keles et al., 2009) evaluated as few as 2 PE film layers for preserving baled silage crops. Each study found some combination of less desirable fermentation products, a higher final $\mathrm{pH}$, and deterioration of nutritive value compared with 4 or more PE film layers, and thereby concluded that 2 layers were insufficient for acceptable fermentation or nutrient preservation (or both). Keller et al. (1998) conducted a similar evaluation and concluded that greater numbers of undesirable microorganisms were present with $4 \mathrm{PE}$ film layers compared with 6,8 , or 10 layers, and that a 4-layer wrapping protocol could not guarantee successful preservation of 


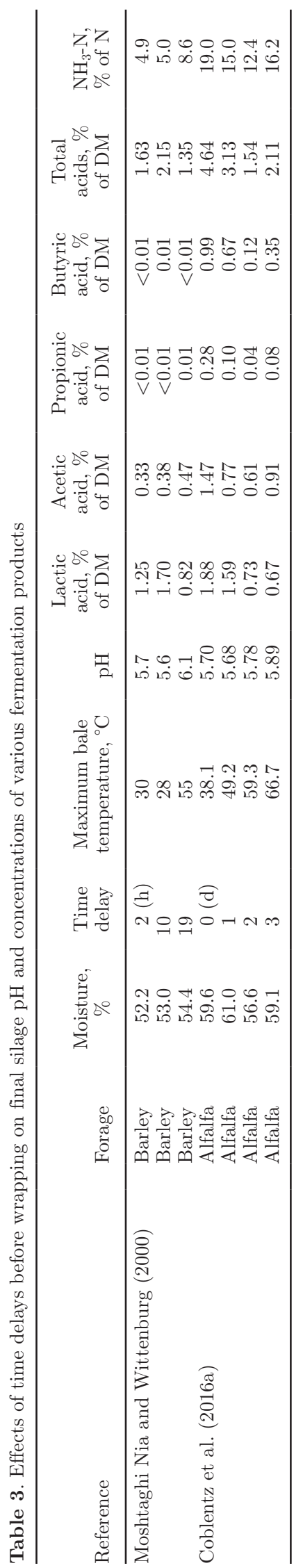

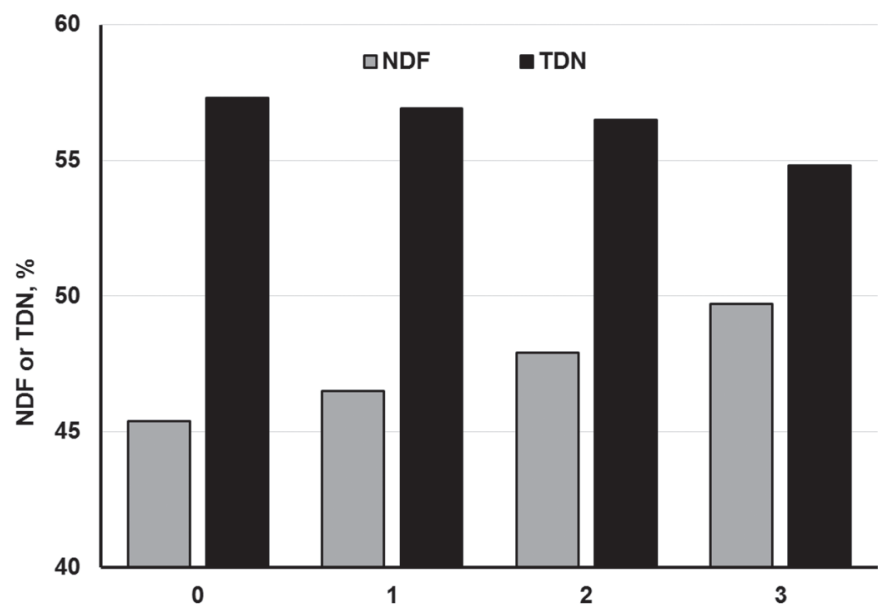

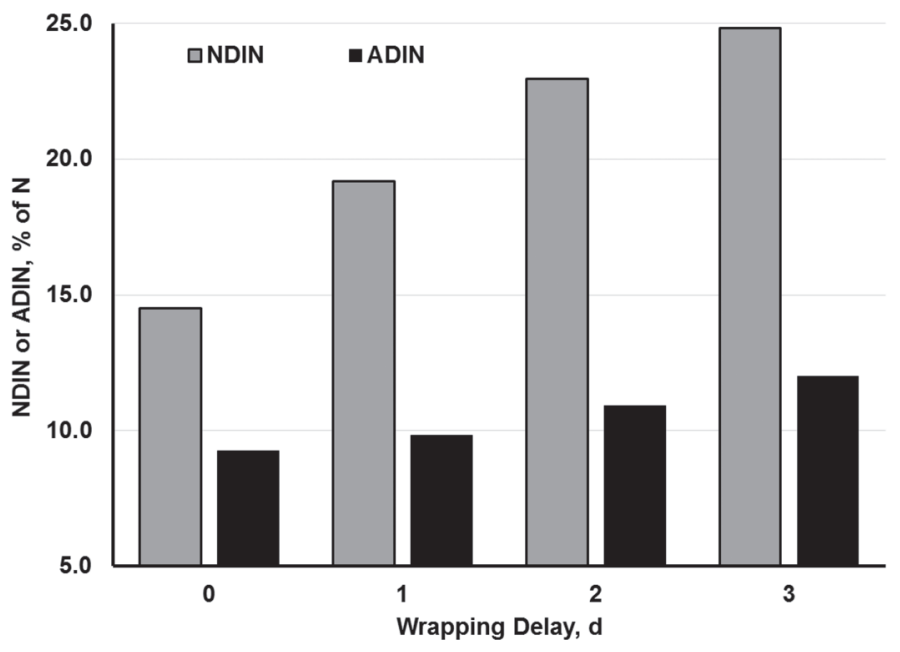

Figure 4. Relationships between concentrations of NDF or TDN (top) and NDIN or ADIN (bottom) with length of wrapping delay (d) for bales of alfalfa silage (Coblentz et al., 2016a). All response variables exhibited linear effects of wrapping delay, and NDIN and TDN also displayed significant quadratic character.

baled alfalfa silages. In part, these responses can be attributed to internal puncture of the PE film by rigid alfalfa stems, thereby rendering the wrap permeable to air. Coblentz et al. (2016c) reported little difference in silage fermentation or nutritive value when alfalfamixed grass silages were wrapped with 4,5 , or $6 \mathrm{PE}$ film layers, but it was noted that the risk of puncture was noticeably greater along bale edges between the flat-end and rounded-circumferential surfaces of the bale. Similar risks of internal puncture have been noted by Borreani and Tabacco (2008). Given these results, it seems likely that 4 1-mil $(0.025-\mathrm{mm}) \mathrm{PE}$ film layers will establish acceptable anaerobiosis for fermentation, but this wrapping standard might not be acceptable to silage producers because of risks of internal or external puncture by rigid stems, vermin, or during additional handling and stacking. 
To some degree, these concepts have been illustrated further in Ireland (O'Brien et al., 2007a); well-managed grass silages were wrapped with 6 layers of $\mathrm{PE}$ film and stored under controlled conditions for $6 \mathrm{wk}$, and then compared with on-farm-produced bales wrapped in 4 $\mathrm{PE}$ film layers and stored for 8 mo before sampling. Visual assessments of fungal contamination were observed on the surface of 15 of 18 on-farm bales, but none were observed on the well-managed bales. Furthermore, damage to the PE film was observed for 8 of 18 on-farm bales, and yeast and mold counts were numerically greater for these bales, emphasizing the practical importance of applying adequate film layers, not just for optimizing fermentation, but also to maintain the integrity of the PE film during handling and subsequent storage. Similar conclusions were offered following assessments of on-farm-produced silages $(\mathrm{n}=$ 100 bales) offered to livestock during winter months in Ireland, in which $49 \%$ of bales exhibited some visual damage to the $\mathrm{PE}$ film, and visual fungal growth was observed on $90 \%$ of all the bales examined (O'Brien et al., 2007b). In $80 \%$ of the 50 farms surveyed, producers noted they used 4 layers of PE film, suggesting this level of security may not be adequate for extended storage, which ranged from 14 to 41 wk throughout this study.

Some manufacturers have offered thicker (1.5-mil; $0.038-\mathrm{mm}$ ) PE film for wrapping bales, and this has been evaluated in a series of studies conducted in Wisconsin (Undersander et al., 2003). Bales were wrapped in in 1.0-mil-thick (normal) and 1.5-mil-thick (thicker) PE films applied in $2,3,4,5,6,7,8,9$, or 10 layers to large-square $(0.9 \times 0.8 \times 1.5-\mathrm{m})$ bales of alfalfa. Conclusions drawn were generally consistent with other work; a cumulative PE film thickness of at least 6 mil $(0.152 \mathrm{~mm})$ was determined to be adequate for good silage preservation, regardless of whether it was applied in six 1-mil-thick layers or four 1.5-mil-thick layers. Furthermore, to obtain greater security against aerobic deterioration resulting from puncture or tears in the $\mathrm{PE}$ film, a cumulative total film thickness of 8 mil (0.203 $\mathrm{mm}$ ) was recommended.

A recent technology has been evaluated by Tabacco et al. (2013) in which bales were tied with PE tying film before wrapping and compared with bales tied with a standard net-type system. Results of that study suggest that the numbers of holes could be reduced, and anaerobic status of bales generally improved by using tying film. These benefits were observed with as few as 4 PE film layers, and might offer potential for improved maintenance of silo integrity without increased cost.

Oxygen-Limiting Barriers. Recently, several studies have examined the concept of inserting an oxygenlimiting barrier into PE films to limit the transmission of oxygen across the layers of film encasing each bale. In addition to increasing the impermeability of bale film to air, this concept potentially offers the opportunity to reduce film usage, lower costs, and partially alleviate the disposal problem for used silage plastics. Positive effects of inserting an oxygen-limited barrier have been reported by Borreani and Tabacco (2008) in a series of experiments with baled alfalfa silages in Italy. Generally, these experiments demonstrated improvements in final silage $\mathrm{pH}, \mathrm{DM}$ recovery, surface mold, as well as surface yeast and mold counts (30-mm depth) when bales were wrapped with PE film containing an oxygen barrier compared with no oxygen barrier (Figure 5). Additional studies by the same research group (Borreani and Tabacco, 2010) compared 2 oxygen-barrier films against standard film, demonstrating consistent reductions in surface mold, mold spots, as well as lower yeast and mold counts in the 120 -mm surface layer for bales wrapped with oxygen-limiting barrier films. In the same set of experiments, reduced yeast counts were observed in the bale core (121-480 $\mathrm{mm}$ depth) in 2 of 3 trials, and reduced mold counts in all 3 trials, suggesting improvements were obtained consistently, even at the bale core, by insertion of an oxygen-limiting barrier. A meta-analysis (Wilkinson and Fenlon, 2013) that included studies with various silo types concluded that PE films with an oxygen-limiting barrier reduced losses from the outer layers of the silo and from bales, and improved aerobic stability during feed-out.

Other studies evaluating the benefits of oxygenlimiting barriers embedded within PE films have been less conclusive. Although an oxygen-limiting barrier had little effect on the preservation or nutritive value of alfalfa-mixed grass silages, Coblentz et al. (2016c) observed that whenever yeast and mold counts were elevated, this infrequent occurrence usually was associated with silages preserved without an oxygen-limiting barrier. Taken in total, oxygen-limiting barriers inserted into PE films have shown positive benefits on the preservation of baled silages in several experiments, but mixed or inconclusive results in others; however, this should not preclude continued investigations of potential benefits of oxygen barriers, and under what conditions the best effects on silage preservation might be obtained.

Length of Storage. The most obvious inherent difference between baled and chopped silages is the reduced rate and extent of fermentation in long-stemmed baled forages (Nicholson et al., 1991; Figure 2); however, this comprehensive early research evaluated only a relatively short $(\leq 60-\mathrm{d})$ postbaling and wrapping period. Studies including longer storage periods are summarized in Table 4. Research by Müller et al. (2007) with baled cool-season grasses indicated that significant fermentation occurred between 2 and 14 mo 

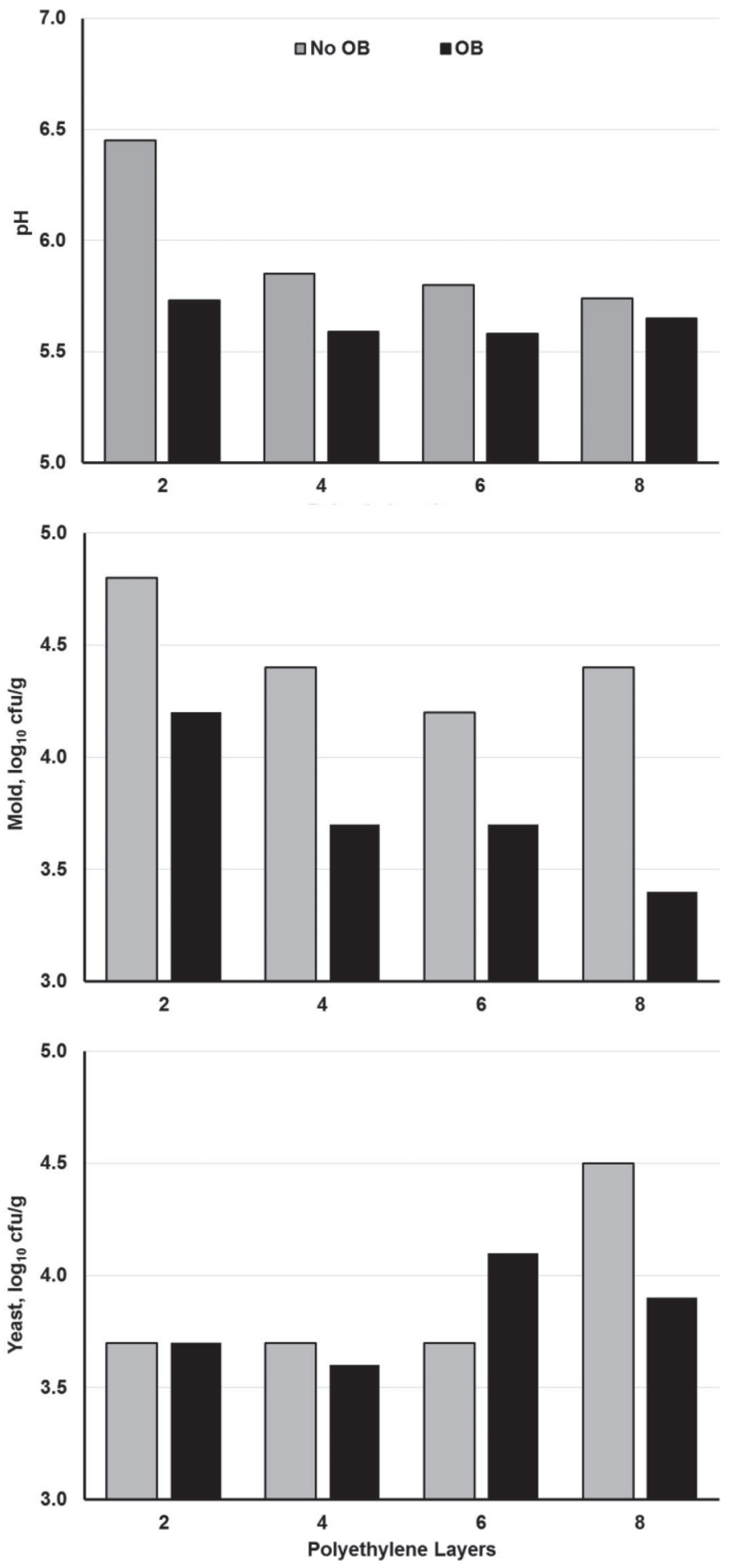

Figure 5. Summary of $\mathrm{pH}$ (top), as well as mold (middle) and yeast (bottom) counts for alfalfa baled silages wrapped with 2, 4, 6, or 8 layers of polyethylene film that contained an oxygen-limiting barrier $(\mathrm{OB})$ or no barrier. Data are adapted from Borreani and Tabacco (2008) and represent the 0- to $30-\mathrm{mm}$ surface layer of each bale. of storage. A unique study was conducted in Puerto Rico (González and Rodriguez, 2003) with warm-season grasses in which concentrations of WSC were low at ensiling $(0.18 \%)$, but increased significantly over the 111 $\mathrm{d}$ of storage concomitantly with reduced concentrations of NDF and hemicellulose. Moreover, the fermentation of warm-season grasses was extremely slow, with increased concentrations of acetic acid observed between 53 and $111 \mathrm{~d}$ postensiling.

Another unique long-term response was observed by Coblentz et al. (2016b) for fall-grown oat (Avena sativa $\mathrm{L}$.) harvested at the boot stage of growth in midNovember in Wisconsin. Initial concentrations of WSC were very high $(22.6 \%)$, while baling and wrapping with PE film immediately preceded the onset of freezing ambient temperatures that maintained internal bale temperatures below freezing until mid-April. Under these conditions, 3 unique responses occurred: (1) silage fermentation was essentially nil until internal bale temperatures warmed to greater than freezing in the spring; (2) once internal bale temperatures exceeded freezing, fermentation occurred extensively; and (3) silage fermentation included significant production of ethanol ( $5.82 \%$ of DM), likely due to high concentrations of WSC that were subject to anaerobic action by yeasts, thereby resulting in increased concentrations of fiber components, as well as losses of DM and TDN. A companion experiment with fall oat harvested at the early heading stage of growth yielded similar responses that included a similar final ethanol concentration of $4.85 \%$ of DM on May 15. Under these circumstances, recommendations were made for feeding fall-oat silage before spring when fermentation was fully initiated. In general, fermentation of baled silages is likely to occur at a slower rate with continuing production of fermentation products at time intervals from wrapping and sealing that may extend longer than those typically observed for chopped silages.

\section{Listeria}

Listeria monocytogenes is a microorganism that causes listeriosis, a serious disease affecting both animals and humans. The presence of this microorganism has been reported widely in raw milk, and its presence may occur via fecal contamination of teat ends during milking (Vissers et al., 2007). This problem is a particular concern in the production of certain soft cheeses, often in Europe, that are made without pasteurization (Lundén et al., 2004). Historically, listeriosis in livestock, especially sheep, has been associated with both the feeding of poor-quality silages, as well as the use of human sewage sludge or livestock slurry as soil amendments, and has been summarized by McDonald 


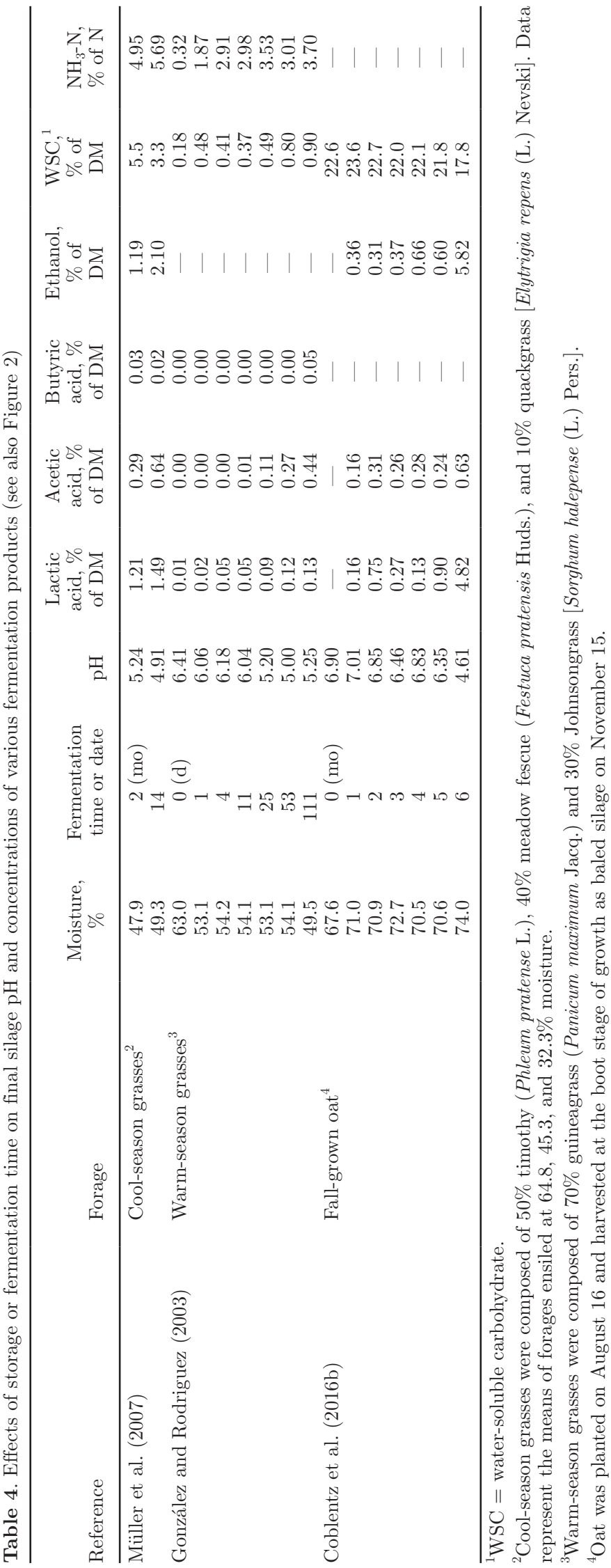

et al. (1991). Within that discussion, it was noted that increased incidence of listeriosis, mostly in Europe, might be correlated with the development of baledsilage techniques, and that early use of pre-formed bags to create anaerobiosis might have facilitated proliferation of Listeria by allowing low levels of oxygen into the sealed bale, particularly through the tied end of the bag. Furthermore, the slow fermentation rate known to occur in baled silages (Nicholson et al., 1991) might add to a favorable environment for growth of Listeria $(\mathrm{Nu}-$ cera et al., 2016). While acknowledging that preformed silage bags are now rarely used, recent research (Nucera et al., 2016) suggests that Listeria are a fairly common component of the pre-ensiled microflora adhered to forages, and that their survival and proliferation is likely associated with aerobically compromised silages that exhibit visual areas of fungal contamination, elevated counts of aerobic yeasts or molds (or both), and an elevated pH. Furthermore, modeling efforts by Ruxton and Gibson (1995) suggest that the fraction of the bale that is hazardous for Listeria increases rapidly with puncture size, but even small punctures could be problematic because of the potential time interval between puncture and feeding. One remedy suggested to partially alleviate this risk is strict attention to loss of anaerobiosis via damage to PE film, which would be less likely by using more wrapping layers (Nucera et al., 2016).

\section{Inoculants and Additives}

Temperate Forages. Although efforts to improve the fermentation and aerobic stability of baled silages have been limited compared with precision-chopped silages, a few studies have investigated the potential of various inoculants and additives for this purpose. Keller et al. (1998) evaluated a cocktail of bacterial inoculants (Lactobacillus plantarum and Enterococcus faecium) coupled with an enzyme preparation containing endoglucanase, $\beta$-glucosidase, and xylanase activities on the fermentation of alfalfa silages baled at $64.0 \%$ moisture that were either pre-chopped in the baler or were baled without particle-size reduction. The cocktail mixture improved production of lactic acid, limited yeast counts, and reduced the final $\mathrm{pH}$ for the unchopped baled silage after $150 \mathrm{~d}$ of storage; however, the pre-chopped silages were not affected by additive treatment. However, in an associated trial conducted at a lower moisture concentration $(53.0 \%)$, the final $\mathrm{pH}$ of chopped silages was made more acidic by using the cocktail additive. Research in Ireland (McEniry et al., 2007a) showed that the addition of sucrose to unchopped grass ensiled in laboratory-scale silos did not improve silage fermentation, but inoculation with 
lactic-acid-producing bacteria reduced final silage $\mathrm{pH}$. Furthermore, when sucrose was combined with the lactic-acid-producing inoculant, the combination of these additives further improved fermentation by reducing final silage $\mathrm{pH}$, as well as concentrations of butyric acid. However, the aerobic stability of these silages was poorer, primarily due to a predominantly lacticacid fermentation, and greater activity of yeasts when laboratory silos were exposed to air. Generally, benefits to fermentation observed with additions of lactic-acidproducing bacteria alone or lactic-acid-producing bacteria plus sucrose were not observed whenever grasses were chopped before ensiling. Other research conducted in South Africa (Meeske et al., 2002) found that inoculation with a cocktail containing lactic-acid-producing bacteria, cellulase, hemicellulase, and amylase did not affect the final $\mathrm{pH}$, or lactic, acetic, and propionic acid concentrations of oat silages, but it did reduce the concentration of butyric acid and improve DMI, as well as milk production by Jersey cows.

Bermudagrass. Ensiling perennial warm-season grasses, such as bermudagrass, often presents unique challenges, in part because of limited concentrations of fermentable carbohydrate to support silage fermentation, as well as a tendency for greater buffering capacities compared with many other grasses (Buxton and O'Kiely, 2003). Research with bermudagrass baled silages in Florida (Arriola et al., 2015) found that several bacterial inoculants improved fermentation by reducing final silage $\mathrm{pH}$ (4.57 to 4.89) compared with an untreated control (5.37). Furthermore, inoculants tended to reduce mold counts, and improved aerobic stability after bale opening, but had no effect on the fiber composition or fiber digestibility of baled bermudagrass silages. Other research (Vendramini et al., 2016) with silage additives (molasses or bacterial inoculants) applied to bermudagrass forages ensiled in laboratory-scale silos found that addition of molasses reduced $\mathrm{pH}$ when silage was wet $(77.5 \%$ moisture $)$, but had little effect at a recommended moisture concentration for baled silages $(47.4 \%)$. The addition of molasses to drier silages increased mold counts (2.7 vs. $1.3 \log \mathrm{cfu} / \mathrm{g}$ ), and affected aerobic stability negatively compared with control silages receiving no additives or inoculants. These responses were attributed to greater residual WSC following addition of molasses without a concurrent increase in production of antifungal acids. In a companion experiment with $340-\mathrm{kg}$ beef heifers, addition of molasses to "Jiggs" bermudagrass packaged in large-round bales reduced final silage $\mathrm{pH}$ (4.1 vs. $4.7)$, increased final concentrations of lactic acid $(2.0$ vs. $0.6 \%$ ), improved voluntary DMI (1.7 vs. $1.4 \% \mathrm{BW}$ ), and increased apparent DM digestibility.

\section{Storage Site Selection and Management}

General recommendations for appropriate selection of storage sites have been described frequently within extension and other published resources (Savoie and Jofriet, 2003; Jennings, 2011; Hersom and Kunkle, 2014); most are logical and have changed little over time. The primary objective is to select a well-drained site that is free of debris, sharp objects, and is not conducive for harboring rodents or other vermin that could puncture the PE-film wrap encasing the bales. One unique study (McNamara et al., 2002) examined this concern, specifically for damage by birds; the PEfilm wrap surrounding bales of cool-season grass was intentionally punctured with $0,1,10$, or 50 small holes (3 $\mathrm{mm}$ diameter), or 1 large hole (21.2 $\mathrm{mm}$ diameter) and stored for $155 \mathrm{~d}$. Conclusions drawn from this study were that holes, such as those simulating damage made by rooks, can cause potentially serious quantitative and qualitative forage losses (Figure 6), and that these losses are likely exacerbated in drier silages. Some resources recommend that bales be positioned with a north-south orientation or on a north-facing slope (Garthe and Hall, 1992; Jennings, 2011) to avoid temperature fluctuations, and possible migration of water within the bales. Commonly, extension recommendations include suggestions for storage in shady areas or stacking of individually wrapped bales to avoid some of these problems, but a study conducted in Puerto Rico (González and Rodriguez, 2003) with baled warmseason grasses found no differences in nutritive value or fermentation characteristics between storage in the shade compared with direct sunlight. Another project (Han et al., 2014) examined the effects of bale order within in-line wrapped bales, and concluded that bale location within the row had little effect on the preservation of annual ryegrass silages in Louisiana.

\section{Aerobic Stability}

Producers often ask questions about the expected aerobic stability of baled silages after exposure to air. This is particularly relevant when bales are wrapped with an in-line wrapper, and the producer must feed livestock at a distant location, or wants to market the baled silage. Under those conditions, a significant number of bales might be exposed at one time, resulting in questions concerning a projected time interval for use before significant aerobic deterioration occurs. In many production systems, such as beef cow-calf, marketing or feeding baled silages would most likely occur during winter months when temperatures are cooler. This paradigm was investigated by Rhein et al. (2005); 21 bales 
of fermented orchardgrass and wheat silages ensiled with an in-line wrapper were exposed to air simultaneously in mid-December in Arkansas, and then sampled after $0,2,4,8,16,24$, or $32 \mathrm{~d}$. The ambient temperature range during the 32-d exposure interval was 0.6 to $19.4^{\circ} \mathrm{C}$. Generally, the nutritive value, $\mathrm{pH}$, and concentrations of fermentation products changed only minimally during this time period, suggesting there is considerable flexibility during winter months for marketing and feeding exposed baled silages. Contrasting climatic conditions in Puerto Rico were evaluated by González and Rodriguez (2003) for baled warm-season grasses that were fermented for 53 or $111 \mathrm{~d}$ in either direct sunlight or shade, and then exposed to air for 3
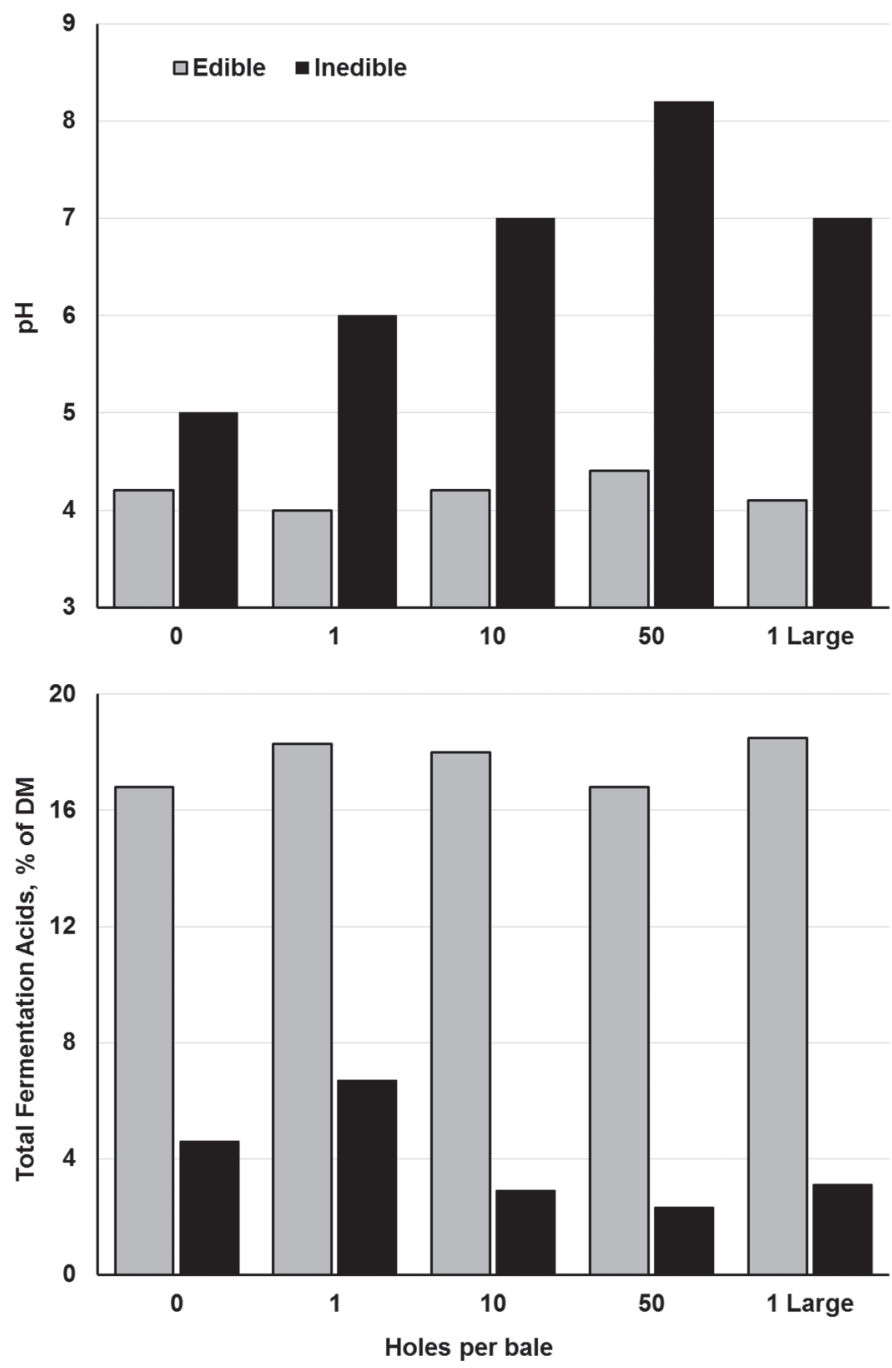

Figure 6. Contrasts of $\mathrm{pH}$ (top) and total fermentation acids (bottom) from edible and inedible (visually aerobically deteriorated) portions of baled grass silages in Ireland. Bales were intentionally punctured with $0,1,10$, or 50 small $(3-\mathrm{mm})$ holes, or 1 large $(21.2-\mathrm{mm})$ hole to simulate bird damage, and then stored for $155 \mathrm{~d}$. Data are adapted from McNamara et al. (2002). d to evaluate aerobic stability. After exposure to air, no differences were observed between direct sunlight or shaded storage at $53 \mathrm{~d}$ postensiling, but bales stored in direct sunlight exhibited greater $\mathrm{pH}$ (7.25 vs. 4.76), internal bale temperature 48.2 vs. $27.0^{\circ} \mathrm{C}$ ), and yeast and mold counts (6.61 vs. $1.50 \log _{10} \mathrm{cfu} / \mathrm{g}$ ) at $111 \mathrm{~d}$ postensiling compared with bales stored in the shade. The opportunity window for use of baled silages is likely to be highly dependent on ambient temperature, with a more favorable climate for silage stability during the winter months throughout most of the continental United States compared with Puerto Rico.

\section{Other Considerations}

Manured Forages. Questions often are asked about the risks of applying dairy slurry to growing alfalfa or other forages. A recent study (Coblentz et al., 2014) compared counts of Clostridium cluster 1 after applications of dairy slurry to the second and third cuttings of alfalfa in Wisconsin. Dairy slurry was applied at a rate of about 42,000 L/ha immediately after the previous harvest was removed (stubble), or after 1 or 2 wk of regrowth (Figure 7). Clostridial counts were increased with any timing of slurry application compared with no slurry, but counts also increased as application of slurry was delayed, thereby decreasing the time interval between application and the subsequent harvest. Clostridial counts were always greater on a postensiled compared with a preensiled basis. Although none of these baled silages had elevated concentrations of butyric acid or $\mathrm{NH}_{3}-\mathrm{N}$, the elevated counts associated with slurry application indicate increased risk, and use of a homofermentative lactic-acid-producing inoculant or additional wilting before baling was advised as a routine precaution.

Ergot Alkaloids/Ergovaline in Tall Fescue Silages. Although tall fescue [Lolium arundinaceum (Schreb.) Darbysh. = Schedonorus arundinaceus (Schreb.) Dumort.] is observed commonly throughout the United States, it is known to host a fungal endophyte, Neotyphodium coenophialum [(Morgan Jones and Gams) Glenn, Bacon, and Hanlin comb. Nov.; Glenn et al., 1996], that produces compounds toxic to livestock. Historically, the relative toxicity of these forages has been assessed by quantifying either ergovaline (an ergopeptine alkaloid) or total ergot alkaloids; however, there have been only a limited number of assessments of tall fescue silages in this respect. Recently, Roberts et al. (2015) evaluated tall fescue silages baled at high (65 to $68 \%$ ) and low (34 to 40\%) bale moistures at locations in northern and southern Missouri. Concentrations of ergovaline decreased by 24 to $58 \%$ as a result of ensiling, regardless of bale moisture or location; how- 


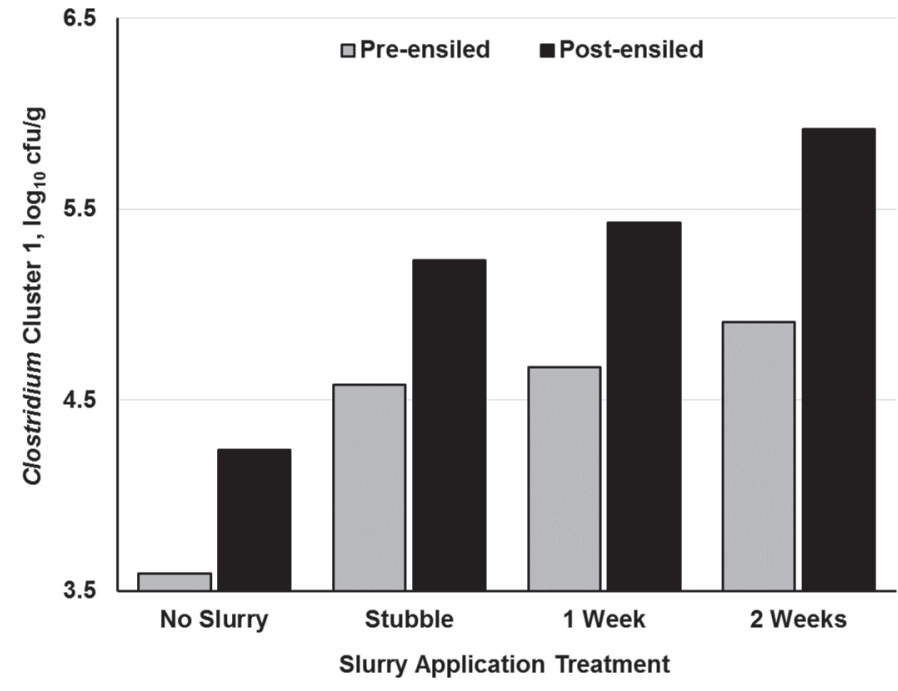

Figure 7. Counts of Clostridium cluster 1 for pre- and postensiled baled alfalfa silages following applications of dairy slurry directly to stubble, or after 1 or $2 \mathrm{wk}$ of regrowth. Counts were determined by quantitative PCR techniques, and Clostridium tyrobutyricum was not found in any baled silage before or after fermentation. Data represent means of 2 harvests, taken after 40 and $32 \mathrm{~d}$ of growth, and are adapted from Coblentz et al. (2014).

ever, total ergot alkaloids increased in high-moisture silages at both locations, but there was no change in concentrations within low-moisture baled silages. These results suggested that markers of potential fescue toxicity were affected by both analyte and silage moisture concentration, and that livestock producers should be wary of toxicity assessments for silages based solely on ergovaline. Ensiling low-moisture fescue forages might offer some potential for reducing concentrations of ergovaline without concomitant increases in total ergot alkaloids.

\section{CONCLUSIONS}

The option of preserving forages as baled silage has increased rapidly in popularity over the last 2 decades, particularly for small and mid-sized dairy and beef producers. There are several reasons for this trend, and the most prominent is a reduced risk of weather damage to valuable forage crops compared with preservation as dry hay. Although most management principles for baled silages remain similar to those for precision-chopped silages, there are some notable differences between silage types. Typical recommendations for forage moisture (45 to 55\%) within baled silages are somewhat drier than those for precision-chopped silages. Additional wilting, coupled with the longstemmed nature of most baled silages, acts to restrict the rate and extent of fermentation for baled silages, thereby suggesting emphasis should be continued on maintaining anaerobiosis through: (1) applying PE-film wraps promptly; (2) using an appropriate number of PE-film layers (6 to 8); (3) selecting a storage site free of sharp objects or other debris; and (4) monitoring wrapped bales closely for evidence of puncture, particularly by birds or vermin. Because of the inherently restricted nature of fermentation within many baled silages, it is questionable whether small improvements in fermentation facilitated through inoculants or other additives will improve silage preservation, or the subsequent performance by livestock consuming these silages. As such, future research with inoculants and additives might best be directed at particularly challenging forages or harvest situations. Potentially, these might include forages with very low WSC concentrations, high buffering capacity, high $(>60 \%)$ moisture concentrations, or forages otherwise compromised by rain damage or clostridial loads following manure application. The restricted nature of fermentation within baled silages also will likely increase residual WSC relative to precision-chopped silages; therefore, inoculants or inoculant cocktails designed to improve aerobic stability might be especially beneficial, particularly if feeding may occur during summer months. Recent efforts to develop PE-film wraps embedded with an oxygen-limiting barrier have often yielded positive results, but most differences between these novel film formulations and reputable commercial PE-film wraps have been limited to more desirable counts of yeasts and molds at the surface layer, rather than improved fermentation or nutritive value on a whole-bale basis. Baled silages can be produced successfully by adhering to straightforward management principles, often using much of the same equipment necessary for making dry hay. As such, this form of silage production is likely to remain popular, especially with small and mid-sized producers, for the foreseeable future.

\section{ACKNOWLEDGMENTS}

Mention of trade names or commercial products in this article is solely for the purpose of providing specific information, and does not imply either recommendation or endorsement by the US Department of Agriculture. Project supported by appropriated USDA-ARS funds through CRIS \#5090-12630-005-00D.

\section{REFERENCES}

Arriola, K. G., O. C. M. Queiroz, J. J. Romero, D. Casper, E. Muniz, J. Hamie, and A. T. Adesogan. 2015. Effects of microbial inoculants on the quality and aerobic stability of bermudagrass roundbale haylage. J. Dairy Sci. 98:478-485. 
Beck, P. A., C. B. Stewart, H. C. Gray, J. L. Smith, and S. A. Gunter. 2009. Effect of wheat forage maturity and preservation method on forage chemical composition and performance of growing calves fed mixed diets. J. Anim. Sci. 87:4133-4142.

Borreani, G., D. Giaccone, A. Mimosi, and E. Tabacco. 2007. Comparison of hay and haylage from permanent Alpine meadows in winter dairy cow diets. J. Dairy Sci. 90:5643-5650.

Borreani, G., and E. Tabacco. 2006. The effect of a baler chopping system on fermentation and losses of wrapped big bales of alfalfa. Agron. J. 98:1-7.

Borreani, G., and E. Tabacco. 2008. New oxygen barrier stretch film enhances quality of alfalfa wrapped silage. Agron. J. 100:942-948.

Borreani, G., and E. Tabacco. 2010. Use of new plastic stretch films with enhanced oxygen impermeability to wrap baled alfalfa silage. Trans. ASAE 53:635-641.

Brito, A. F., G. F. Tremblay, A. Bertrand, Y. Castonguay, G. Bélanger, R. Michaud, H. Lapierre, C. Benchaar, H. V. Petit, D. R. Ouellet, and R. Berthiaume. 2008. Alfalfa cut at sundown and harvested as baleage improves milk yield of late-lactation dairy cows. J. Dairy Sci. 91:3968-3982.

Burns, J. C., and D. S. Fisher. 2012. Intake and digestibility of big bluestem hay and baleage. Crop Sci. 52:2413-2420.

Buxton, D. R., and P. O'Kiely. 2003. Preharvest plant factors affecting ensiling. Pages 199-250 in Silage Science and Technology. D. R. Buxton, R. E. Muck, and J. H. Harrison, ed. American Society of Agronomy, Crop Science Society of America, and Soil Science Society of America, Madison, WI.

Coblentz, W. K., K. P. Coffey, and E. A. Chow. 2016a. Storage characteristics, nutritive value, and fermentation characteristics of alfalfa packaged in large-round bales and wrapped in stretch plastic film after extended time delays. J. Dairy Sci. 99:3497-3511.

Coblentz, W. K., and P. C. Hoffman. 2009. Effects of bale moisture and bale diameter on spontaneous heating, dry matter recovery, in vitro true digestibility, and in situ disappearance kinetics of alfalfaorchardgrass hays. J. Dairy Sci. 92:2853-2874.

Coblentz, W. K., and P. C. Hoffman. 2010. Effects of spontaneous heating on estimates of TDN for alfalfa-orchardgrass hays packaged in large-round bales. J. Dairy Sci. 93:3377-3389.

Coblentz, W. K., R. E. Muck, M. A. Borchardt, S. K. Spencer, W. E. Jokela, M. G. Bertram, and K. P. Coffey. 2014. Effects of dairy slurry on silage fermentation characteristics and nutritive value of alfalfa. J. Dairy Sci. 97:7197-7211.

Coblentz, W. K., R. E. Muck, and J. S. Cavadini. 2016b. Fermentation of fall-oat balage over winter in northern climates. Crop, Forage, \& Turfgrass Manage. Online (Bergh.) https://doi.org/10.2134/ cftm2014.0110.

Coblentz, W. K., R. K. Ogden, M. S. Akins, and E. A. Chow. 2016c. Storage characteristics, nutritive value, and fermentation characteristics of large, round bales of alfalfa-mixed grass forage wrapped with different layers of stretch film. Prof. Anim. Sci. 32:805-815.

Collins, M., L. D. Swetnam, G. M. Turner, J. N. Hancock, and S. A. Shearer. 1995. Storage method effects on dry matter and quality losses of tall fescue round bales. J. Prod. Agric. 8:507-514.

Garces-Yépez, P., R. Cromwell, W. E. Kunkle, D. Bates, and C. Chambliss. 2001. Effect of delayed wrapping on bermudagrass ensiled in round bales wrapped with plastic. 2001 Beef Research Reports. Department of Animal Science, University of Florida, Gainesville.

Garthe, J. W., and M. H. Hall. 1992. Large round bale silage. Agronomy Facts 9. Penn State Cooperative Extension, University Park, PA. Accessed Dec. 7, 2016. http://extension.psu.edu/plants/ crops/forages/hay-and-silage/preservation/large-round-bale-silage $-\mathrm{x}$.

Glenn, A. E., C. W. Bacon, R. Price, and R. T. Hanlin. 1996. Molecular physiology of Acremonium and its taxonomic implications. Mycology 88:369-383.

Goering, H. K., P. J. Van Soest, and R. W. Hemken. 1973. Relative susceptibility of forages to heat damage as affected by moisture, temperature, and pH. J. Dairy Sci. 56:137-143.

González, G., and A. A. Rodriguez. 2003. Effect of storage method on fermentation characteristics, aerobic stability, and forage intake of tropical grasses. J. Dairy Sci. 86:926-933.
Han, K. J., M. Collins, M. C. Newman, and C. T. Daughterty. 2006. Effects of forage length and bale chamber pressure on pearl millet silage. Crop Sci. 46:337-344.

Han, K. J., M. Collins, E. S. Vanzant, and C. T. Dougherty. 2004. Bale density and moisture effects on alfalfa round bale silage. Crop Sci. 44:914-919.

Han, K. J., M. E. McCormick, S. M. Derouen, and D. C. Blouin. 2014 Bale location effects on nutritive value and fermentation characteristics of annual ryegrass bales stored in in-line wrapping silage. Asian-australas. J. Anim. Sci. 27:1276-1284.

Hancock, D. W., and M. Collins. 2006. Forage preservation method influences alfalfa nutritive value and feeding characteristics. Crop Sci. 46:688-694.

Hersom, M., and W. E. Kunkle. 2014. Harvesting, storing, and feeding forages as round bale silage. Publication \#AN145. University of Florida IFAS Extension, Gainesville, FL.

Holmes, B. J., and R. E. Muck. 2008. Packing bunker and pile silos to minimize porosity. Focus on Forage. Vol. 10. No. 1. University of Wisconsin-Extension, Madison, WI.

Huhnke, R. L., R. E. Muck, and M. E. Payton. 1997. Round bale silage storage losses of ryegrass and legume-grass forages. Appl. Eng. Agric. 13:451-457.

Huntington, G. B., and J. C. Burns. 2007. Afternoon harvest increases readily fermentable carbohydrate concentration and voluntary intake of gamagrass and switchgrass baleage by beef steers. J. Anim. Sci. 85:276-284.

Jennings, J. A. 2011. Baled silage for livestock. \#FSA3051-PD4-11RV. University of Arkansas Cooperative Extension Service, Little Rock, AR.

Keles, G., P. O'Kiely, J. J. Lenehan, and P. D. Forristal. 2009. Conservation characteristics of baled grass silages differing in duration of wilting, bale density, and number of layers of plastic stretch-film. Ir. J. Agric. Food Res. 48:21-34.

Keller, Th., H. Nonn, and H. Jeroch. 1998. The effect of sealing and of additives on the fermentation characteristics and mould and yeast counts in stretch film wrapped big-bale lucerne silage. Arch. Anim. Nutr. 51:63-75.

Kung, L., and R. Shaver. 2001. Interpretation and use of silage fermentation analysis reports. Focus on Forage. Vol. 3. No. 13. University of Wisconsin Extension and College of Agricultural and Life Sciences. Madison, WI.

Lacy, R. C., J. R. Pruitt, and D. W. Hancock. 2015. Economic returns and risk analysis of forage wrapping technologies. J. Am. Soc. Farm Managers and Rural Appraisers 79:139-153.

Leibensperger, R. Y., and R. E. Pitt. 1987. A model of clostridial dominance in ensilage. Grass Forage Sci. 42:297-317.

Lundén, J., R. Tolvanen, and H. Korkeala. 2004. Human listeriosis outbreaks linked to dairy products in Europe. J. Dairy Sci. 87(E. Suppl.):E6-E11

Mahanna, B., and L. E. Chase. 2003. Practical applications and solutions to silage problems. Pages $855-895$ in Silage Science and Technology. D. R. Buxton, R. E. Muck, and J. H. Harrison, ed. American Society of Agronomy, Crop Science Society of America, and Soil Science Society of America, Madison, WI

McCormick, M. E., G. J. Cuomo, and D. C. Blouin. 1998. Annual ryegrass stored as balage, haylage, or hay for lactating dairy cows. J. Prod. Agric. 11:293-300.

McDonald, P., and R. A. Edwards. 1976. The influence of conservation methods on digestion and utilization of forages by ruminants. Proc. Nutr. Soc. 35:201-211.

McDonald, P., A. R. Henderson, and S. J. E. Heron. 1991. The Biochemistry of Silage. 2nd ed. Chalcombe Publications. Marlow, Buckinghamshire, UK.

McEniry, J., P. O'Kiely, N. J. W. Clipson, P. D. Forristal, and E. M. Doyle. 2006. The microbiological and chemical composition of baled and precision-chop silages on a sample of farms in County Meath. Ir. J. Agric. Food Res. 45:73-83.

McEniry, J., P. O'Kiely, N. J. W. Clipson, P. D. Forristal, and E. M. Doyle. 2007a. Manipulating the ensilage of wilted, unchopped grass through the use of additive treatments. Ir. J. Agric. Food Res. 16:77-91. 
McEniry, J., P. O'Kiely, N. J. W. Clipson, P. D. Forristal, and E. M. Doyle. 2007b. The relative impacts of wilting, chopping, compaction, and air infiltration on the conservation characteristics of ensiled grass. Grass Forage Sci. 45:73-83.

McNamara, K., P. O'Kiely, J. Whelan, P. D. Forristal, and J. J. Lenehan. 2002. Simulated bird damage to the plastic stretch-film surrounding baled silage and its effects on conservation characteristics. Ir. J. Agric. Food Res. 41:29-41.

Meeske, R., G. D. van der Merwe, J. F. Greyling, and C. W. Cruywagen. 2002. The effect of adding an enzyme containing lactic acid bacterial inoculant to big round bale oat silage on intake, milk composition and milk composition of Jersey cows. Anim. Feed Sci. Technol. 97:159-167.

Moshtaghi Nia, S. A., and K. M. Wittenburg. 2000. Effect of delayed wrapping on preservation and quality of whole crop barley forage ensiled as large bales. Can. J. Anim. Sci. 80:145-151.

Muck, R. E. 1988. Factors influencing silage quality and their implications for management. J. Dairy Sci. 71:2992-3002.

Muck, R. E., L. E. Moser, and R. E. Pitt. 2003. Postharvest factors affecting ensiling. Pages 251-304 in Silage Science and Technology. D. R. Buxton, R. E. Muck, and J. H. Harrison, ed. American Society of Agronomy, Crop Science Society of America, and Soil Science Society of America, Madison, WI.

Müller, C. E., T. M. Pauly, and P. Udén. 2007. Storage of small bale silage and haylage-Influence of storage period on fermentation variables and microbial composition. Grass Forage Sci. 62:274-283.

Nicholson, J. W. G., R. E. McQueen, E. Charmley, and R. S. Bush. 1991. Forage conservation in round bales or silage: Effect on ensiling characteristics and animal performance. Can. J. Anim. Sci. 71:1167-1180.

Nucera, D. M., M. A. Grassi, P. Morra, S. Piano, E. Tabacco, and G. Borreani. 2016. Detection, identification, and typing of Listeria species from baled silages fed to dairy cows. J. Dairy Sci. 99:6121-6133.

O'Brien, M., P. O'Kiely, P. D. Forristal, and H. T. Fuller. 2007a. Quantification and identification of fungal propagules in well-managed baled grass silage and in normal on-farm produced bales. Anim. Feed Sci. Technol. 132:283-297.

O'Brien, M., P. O'Kiely, P. D. Forristal, and H. T. Fuller. 2007b. Visible fungal growth on baled silage during winter feeding season in Ireland and silage characteristics associated with the occurrence of fungi. Anim. Feed Sci. Technol. 139:234-256.

Petit, H. V., G. F. Tremblay, P. Savoie, D. Tremblay, and J. M. Wauthy. 1993. Milk yield, intake and blood traits of lactating cows fed grass silage conserved under different harvesting methods. J. Dairy Sci. 76:1365-1374.

Rhein, R. T., W. K. Coblentz, J. E. Turner, C. F. Rosenkrans Jr., R. K. Ogden, and D. W. Kellogg. 2005. Aerobic stability of wheat and orchardgrass round-bale silages during winter. J. Dairy Sci. 88:1815-1826.

Roberts, C. A., D. K. Davis, M. L. Looper, R. L. Kallenbach, G. E. Rottinghaus, and N. S. Hill. 2015. Ergot alkaloid concentrations in high- and low-moisture tall fescue silage. Crop Sci. 54:1887-1892.
Rotz, C. A., and R. E. Muck. 1994. Changes in forage quality during harvest and storage. Pages 828-868 Forage Quality, Evaluation, and Utilization. G. C. Fahey et al., ed. Proc. Natl. Conf. on Forage Quality, Evaluation, and Utilization, Lincoln NE. 13-15 Apr. 1994. American Society of Agronomy, Crop Science Society of America, and Soil Science Society of America, Madison, WI.

Ruxton, G. D., and G. J. Gibson. 1995. A mathematical model of the aerobic deterioration of big-bale silage and its implications for the growth of Listeria monocytogenes. Grass Forage Sci. 50:331-344.

Sauvé, A. K., G. B. Huntington, C. S. Whisnant, and J. C. Burns. 2010. Intake, digestibility, and nitrogen balance of steers fed gamagrass baleage topdressed at two rates of nitrogen and harvested at sunset and sunrise. Crop Sci. 50:427-437.

Savoie, P., and J. C. Jofriet. 2003. Silage storage. Pages 405-468 in Silage Science and Technology. D. R. Buxton, R. E. Muck, and J. H. Harrison, ed. American Society of Agronomy, Crop Science Society of America, and Soil Science Society of America, Madison, WI.

Shinners, K. J. 2003. Engineering principles of silage harvesting management. Pages 361-404 in Silage Science and Technology. D. R. Buxton, R. E. Muck, and J. H. Harrison, ed. American Society of Agronomy, Crop Science Society of America, and Soil Science Society of America, Madison, WI.

Shinners, K. J., B. M. Huenink, R. E. Muck, and K. A. Albrecht. 2009. Storage characteristics of large round and square alfalfa bales: Low-moisture wrapped bales. Trans. ASABE 52:401-407.

Tabacco, E., C. Bisaglia, A. Revello-Chion, and G. Borreani. 2013. Assessing the effect of securing bales with either polyethylene film or netting on the fermentation profiles, fungal load, and plastic consumption in baled silage of grass-legume mixtures. Trans. ASABE 29:795-804.

Undersander, D. J., T. Wood, and W. Foster. 2003. Successful wrapping and storage of square bales. University of Wisconsin-Extension, Madison, WI. Accessed Dec. 7, 2016. http://www.uwex.edu/ ces/forage/wfc/proceedings2003/squarebales.htm.

Van Soest, P. J. 1982. Nutritional Ecology of the Ruminant. Cornell Univ. Press, Ithaca, NY.

Vendramini, J. M. B., A. D. Aguiar, A. T. Adesogan, L. E. Sollenberger, E. Alves, L. Galzerano, P. Salvo, A. L. Valente, K. G. Arriola, Z. X. Ma, and F. C. L. Oliveira. 2016. Effects of genotype, wilting, and additives on the nutritive value and fermentation of bermudagrass silage. J. Anim. Sci. 94:3061-3071.

Vissers, M. M. M., F. Driehuis, M. C. Te Giffel, P. De Jong, and J. M. G. Lankveld. 2007. Short Communication: Quantification of the transmission of microorganisms to milk via dirt attached to the exterior of teats. J. Dairy Sci. 90:3579-3582.

Vough, L. R., and I. Glick. 1993. Round bale silage. Pages 117-123 in Silage Production: From Seed to Animal. Proc. Natl. Silage Production Conference, Syracuse, NY. 23-25 February 1993. Northeast Regional Agricultural Engineering Service, Ithaca, NY.

Wilkinson, J. M., and J. S. Fenlon. 2013. A meta-analysis comparing standard polyethylene and oxygen barrier film in terms of losses during storage and aerobic stability of silage. Grass Forage Sci. 69:385-392. 